\title{
Seasonal variation of diel vertical migration of zooplankton from ADCP backscatter time series data in the Lazarev Sea, Antarctica
}

\author{
Boris Cisewski ${ }^{\mathrm{a}, \mathrm{b}, *}$, Volker H. Strass ${ }^{\mathrm{a}}$, Monika Rhein ${ }^{\mathrm{b}}$, Sören Krägefsky ${ }^{\mathrm{a}}$ \\ ${ }^{a}$ Alfred-Wegener-Institut für Polar und Meeresforschung, P.O. Box 120161, 27515 Bremerhaven, Germany \\ ${ }^{\mathrm{b}}$ Institut für Umweltphysik, Abt. Ozeanographie, Universität Bremen, Otto-Hahn-Allee, 28359 Bremen, Germany
}

\section{A R T I C L E I N F O}

\section{Article history:}

Received 19 December 2008

Received in revised form

30 September 2009

Accepted 8 October 2009

Available online 17 October 2009

Keywords:

Diel vertical migration

ADCP backscatter

Diel and seasonal cycles

Lazarev Sea

Eastern Weddell Sea

\begin{abstract}
A B S T R A C T
Ten-month time series of mean volume backscattering strength (MVBS) and vertical velocity obtained from three moored acoustic Doppler current profilers (ADCPs) deployed from February until December 2005 at $64^{\circ} \mathrm{S}, 66.5^{\circ} \mathrm{S}$ and $69^{\circ} \mathrm{S}$ along the Greenwich Meridian were used to analyse the diel vertical zooplankton migration (DVM) and its seasonality and regional variability in the Lazarev Sea. The estimated MVBS exhibited distinct patterns of DVM at all three mooring sites. Between February and October, the timing of the DVM and the residence time of zooplankton at depth were clearly governed by the day-night rhythm. Mean daily cycles of the ADCP-derived vertical velocity were calculated for successive months and showed maximum ascent and descent velocities of 16 and $-15 \mathrm{~mm} \mathrm{~s}^{-1}$. However, a change of the MVBS pattern occurred in late spring/early austral summer (October/ November), when the zooplankton communities ceased their synchronous vertical migration at all three mooring sites. Elevated MVBS values were then concentrated in the uppermost layers $(<50 \mathrm{~m})$ at $66.5^{\circ} \mathrm{S}$. This period coincided with the decay of sea ice coverage at $64^{\circ} \mathrm{S}$ and $66.5^{\circ} \mathrm{S}$ between early November and mid-December. Elevated chlorophyll concentrations, which were measured at the end of the deployment, extended from $67^{\circ} \mathrm{S}$ to $65^{\circ} \mathrm{S}$ and indicated a phytoplankton bloom in the upper $50 \mathrm{~m}$. Thus, we propose that the increased food supply associated with an ice edge bloom caused the zooplankton communities to cease their DVM in favour of feeding.
\end{abstract}

(c) 2009 Elsevier Ltd. All rights reserved.

\section{Introduction}

Diel vertical migration (DVM) is a widespread behaviour among zooplankton. Although there is considerable variation between and within species, three general DVM patterns have been recognized (Hutchinson, 1967). The most common, so-called nocturnal vertical migration, describes a migration pattern where groups of zooplankton ascend around dusk and remain at a shallower depth during the night. Around dawn, they begin to descend and remain at depth during the day. In contrast to nocturnal migration, reverse migration involves an ascent to shallow water at sunrise and a descent to deeper water at sunset. The third pattern, twilight DVM, involves an ascent to the surface at sunset, then a descent to deeper water around midnight (i.e. the "midnight sink"), followed by a second ascent to the surface and then descent to deeper water at sunrise (Cohen and Forward, 2002).

\footnotetext{
* Corresponding author at: Alfred-Wegener-Institut für Polar und Meeresforschung, P.O. Box 120161, 27515 Bremerhaven, Germany. Tel.: +49 47148311816; fax: +4947148311797 .

E-mail address: Boris.Cisewski@awi.de (B. Cisewski).
}

Despite many decades of study, the proximate factors that directly stimulate the rise and descent of zooplankton, as well as the ultimate factors (biological advantages) of diel vertical migration, are still debated. Proximate factors include biotic (e.g. predators and food) and abiotic factors (e.g. light). Light is agreed to be the most significant external cue in diel vertical migration behaviour, because the times of migration usually correspond to the times of light intensity change underwater at sunrise and sunset (see Roe, 1974; Forward, 1988; Haney, 1988; Ringelberg, 1995). Regarding ultimate factors, the predator evasion hypothesis has gained wide acceptance, which supposes that migration out of the well-illuminated surface layer during daytime substantially decreases mortality of descending animals by reducing the risk of being detected by visually hunting predators (Zaret and Suffern, 1976). However, there are likely other reasons why zooplankton benefit by performing diel vertical migration, which, for example, may include utilization of the oceanic flow field for their horizontal displacement or retention (e.g. Hardy and Gunther, 1935; Manuel and O'Dor, 1997; Manuel et al., 1997).

A paradigm of marine polar biology is that seasonal change in sea ice coverage has a profound influence on ecosystem processes. By late austral winter (August-September), the sea ice around Antarctica typically covers more than 20 million $\mathrm{km}^{2}$ (Gloersen 
and Campbell, 1991; Zwally et al., 2002) and recedes to less than 4 million $\mathrm{km}^{2}$ during spring and summer. For much of the year in the seasonally ice-covered areas of the Southern Ocean most of the biomass and primary production occurs not in the water column but in the overlying sea ice cover (Arrigo and Thomas, 2004). There, the sea ice supports the only significant primary production for up to 9 months of the year because deep mixing, heavy ice cover and low light levels prevent development of significant phytoplankton biomass in the water column (McMinn et al., 2007). During the austral summer, when the ice edge recedes, low-salinity meltwater usually produces a shallow low-density layer that reduces vertical mixing and shallows the mixed layer. Consequently, phytoplankton blooms may develop in a high-irradiance, stable shallow mixed layer environment (Smith and Nelson, 1985) and provide the major food supply for zooplankton at this time. Because diel migrants probably ingest organic material predominantly in the photic zone and excrete part of it at greater depths as dissolved nitrogen and carbon compounds, diel vertical migration may contribute considerably to vertical transport of carbon and nutrients (Longhurst et al., 1990; Longhurst and Williams, 1992).

Most previous studies of vertical migration in the open ocean were conducted using day-night pairs of net tows, which lacked sufficient spatial and temporal resolution to yield precise estimates of its timing, velocity and extent. More recently, the acoustic Doppler current profiler (ADCP) has been proven to be a useful tool to describe spatial and temporal patterns in the distribution of zooplankton biomass in many oceanic regions. In their pioneer study, Flagg and Smith (1989) introduced a method to convert the backscatter intensity measured by ADCPs to biomass using a biomass-intensity regression, which is derived from both discrete net tows and spatially and temporally coincident acoustic backscatter intensities. However, since the ability to determine accurate biomass estimates from acoustic survey techniques is quite dependent on (i) a detailed knowledge of the target strength of species and (ii) the ability to distinguish echoes originating from different target species (Brierley et al., 1998), the use of single-frequency sonars like ADCPs to investigate zooplankton abundance is restricted to a rather qualitative analysis. The scientific use of ADCPs to qualitatively analyse temporal und spatial variability of the backscatter pattern is nevertheless commonly accepted (e.g. Flagg and Smith, 1989; Plueddemann and Pinkel, 1989; Heywood et al., 1991).

This study presents an analysis of echo intensity and vertical velocity data recorded by self-contained ADCPs moored at three different locations $\left(64^{\circ} \mathrm{S}, 66.5^{\circ} \mathrm{S}\right.$ and $\left.69^{\circ} \mathrm{S}\right)$ along the Greenwich Meridian in the Lazarev Sea. The mooring array was embedded in the extensive field campaign of the Lazarev Sea Krill Study (LAKRIS), dedicated to identifying relationships between the physical environment and the abundance of zooplankton and especially krill (Euphausia superba), a key species in the Southern Ocean food web. Logistic hurdles hampering detailed continuous long-term measurements of zooplankton abundance have severely limited the observation and understanding of oceanic ecosystems in remote regions such as the Southern Ocean. Selfcontained ADCPs, which can be deployed in extreme environments and operate autonomously for several months, provided a solution to this problem. The presented long-term time series data of acoustic backscatter enable the first analysis of diurnal vertical zooplankton migration and its seasonality in the Lazarev Sea.

\section{Instrumentation}

\subsection{Self-contained acoustic Doppler current profiler}

The ADCPs used were of the type RDI Workhorse Longranger (Teledyne RD Instruments USA, Poway, California), using a four-beam, convex configuration with a beam angle of $20^{\circ}$ and a frequency of $76.8 \mathrm{kHz}$. The instruments were moored at nominal depths between 317 and $379 \mathrm{~m}$ (Fig. 1a) in upward-looking mode and measured horizontal and vertical currents and acoustic backscatter intensity from roughly 20 to $380 \mathrm{~m}$ (Table 1 ). Heading, pitch and roll, pressure and temperature data were also collected. The ADCPs were employed in two different configurations depending on the instrument's internal data storage capacity. The number of depth cells was either set to 38 with a bin size of $16 \mathrm{~m}$ or set to 80 with a bin size of $8 \mathrm{~m}$. The sampling interval was set to 1 ping per ensemble with a ping rate of about 1 ping every 10 min or 1 ping every 2 min. The moorings were deployed in February 2005 during R.V. Polarstern cruise ANT 22/3 with chief scientist Eberhard Fahrbach and recovered during R.V. Polarstern cruise ANT 23/2.

\subsection{CTD profiler}

Eighty-seven casts with a CTD type Sea-Bird Electronics SBE 911plus were made during the R.V. Polarstern cruise ANT 23/2 between December 06, 2005, and January 02, 2006, in order to map the hydrographic field of the study area at the end of the mooring deployment. Of these, 45 extended to full ocean depth, while the others were limited mostly to the upper $1000 \mathrm{~m}$ of the water column. Except for the first and the last, all CTD stations were organized in a regular grid, made up of four meridional sections running between $60^{\circ} \mathrm{S}$ and $70^{\circ} \mathrm{S}$ along $3^{\circ} \mathrm{E}, 0^{\circ} \mathrm{E}, 3^{\circ} \mathrm{W}$ and $6^{\circ} \mathrm{W}$. Water samples were collected with a Sea-Bird Carousel sampler with $2412-1$ bottles. For in situ calibration, temperatures were measured with a digital reversing thermometer Sea-Bird SBE35, and salinity samples were analysed with a GuildlineAutosal-8400A salinometer onboard. The temperature sensor was calibrated by the manufacturer a few months prior to the cruise and afterwards to an accuracy better than $0.001{ }^{\circ} \mathrm{C}$. Salinity derived from the CTD measurements was calibrated to a final accuracy of better than 0.002 by comparison to the salinity samples.

\subsection{Vessel-mounted acoustic Doppler current profiler}

Current velocities were measured on board R.V. Polarstern continuously using a hull-mounted acoustic Doppler current profiler (Ocean Surveyor; Teledyne RD Instruments USA, Poway, California, $150 \mathrm{kHz}$ nominal frequency). The transducers were located $11 \mathrm{~m}$ below the water line. Heading, roll and pitch data from the ship's gyro platforms were used to convert the ADCP velocities into earth coordinates. The ship's velocity was calculated from position fixes obtained by the Global Positioning System (GPS) or Differential Global Positioning System (DGPS), if available. $U$ (eastward) and $V$ (northward) velocity components were averaged in 2 min ensembles in $4 \mathrm{~m}$ thick depth bins between 19 and $335 \mathrm{~m}$ depth. The reference layer was set to bins $6-15$, avoiding near-surface effects and biases near bin 1 . Accuracy of the ADCP velocities depends mainly on the quality of position fixes and ship's heading data. Further errors stem from a misalignment of the transducer with the ship's centerline. To reduce these errors, standard watertrack calibration methods were applied to provide a velocity scale factor and a constant angular offset between the transducer and the length axis of the ship. Further ADCP processing was done using the CODAS3 software package developed by E. Firing and colleagues (Firing, 1991). Barotropic tidal currents were predicted and removed using the Circumantarctic tidal model CATS 2.01 developed by Padman et al. (2002). 


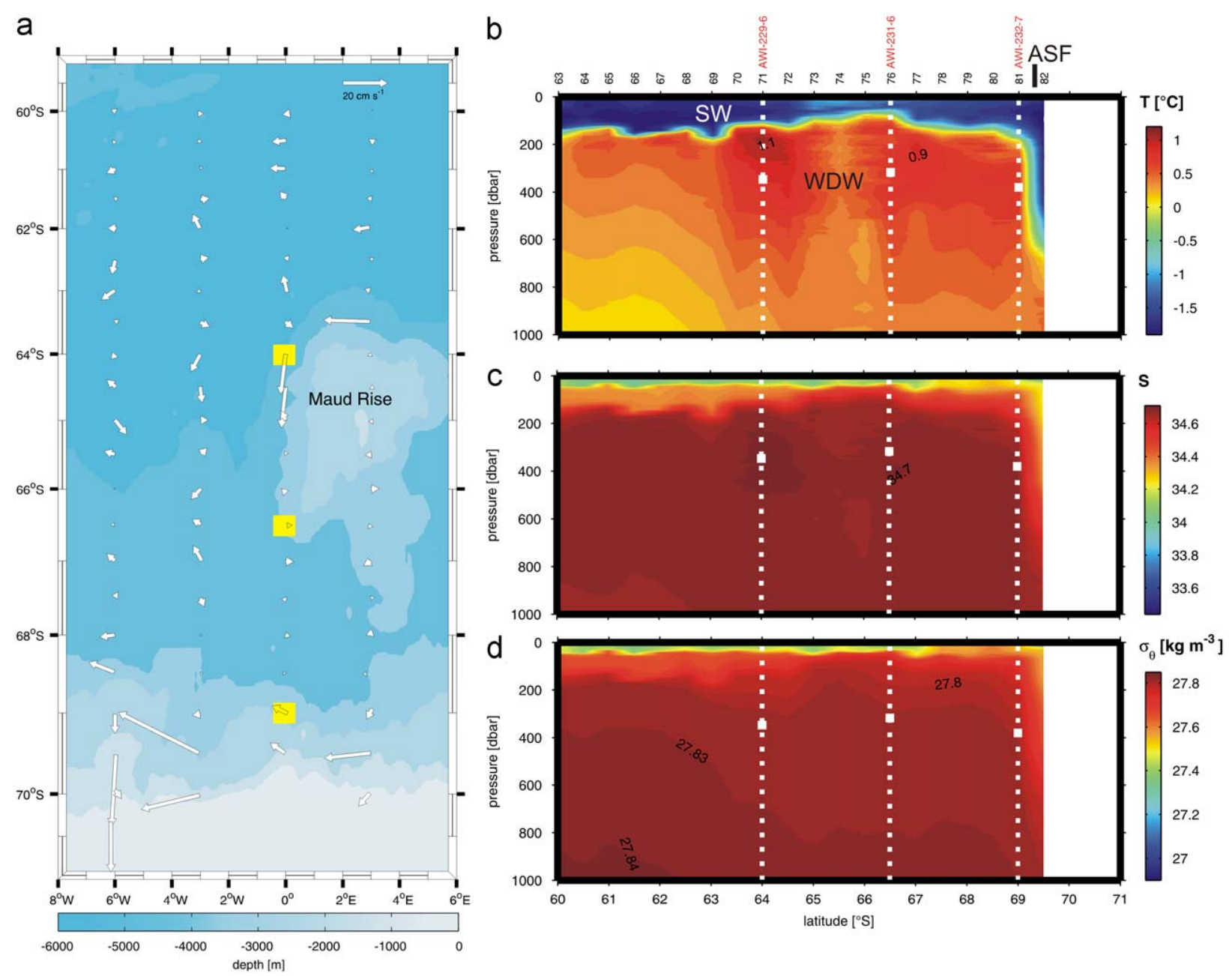

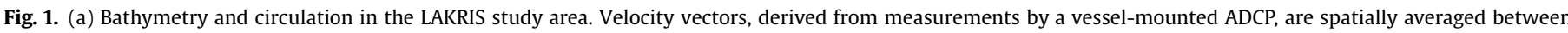

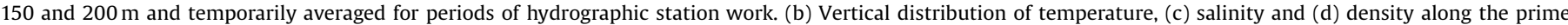

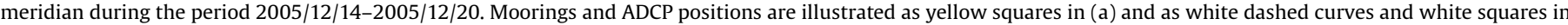
(b)-(d), respectively. ASF, Antarctic Slope Front; SW, Surface Water; WDW, Warm Deep Water.

Table 1

Mooring information.

\begin{tabular}{|c|c|c|c|c|}
\hline Mooring & Position & Water depth (m) & Mean ADCP depth (m) & Time period \\
\hline AWI-229-6 & $\begin{array}{l}63^{\circ} 57.16^{\prime} \mathrm{S} \\
00^{\circ} 00.37^{\prime} \mathrm{W}\end{array}$ & 5200 & $346.9 \pm 56.7$ & Feb. 7, 2005-Dec. 16, 2005 \\
\hline AWI-231-6 & $\begin{array}{l}66^{\circ} 30.66^{\prime} \mathrm{S} \\
00^{\circ} 01.91^{\prime} \mathrm{W}\end{array}$ & 4540 & $317.1 \pm 0.8$ & Feb. 9, 2005-Dec. 18, 2005 \\
\hline AWI-232-7 & $\begin{array}{l}68^{\circ} 59.75^{\prime} \mathrm{S} \\
00^{\circ} 00.11^{\prime} \mathrm{W}\end{array}$ & 3370 & $379.2 \pm 3.0$ & Feb. 17, 2005-Dec. 19, 2005 \\
\hline
\end{tabular}

\subsection{Supplementary data}

Sunrise/sunset times and sun angles at the mooring locations were calculated with the solar position algorithm (SPA) introduced by Reda and Andreas (2004). Since continuous radiation measurements were not available for the mooring sites, a correlation analysis was used to derive the global irradiance as a function of modelled astronomical radiation. Global solar irradiance measurements were available from the Neumayer Station at $70^{\circ} 37^{\prime} \mathrm{S}, 8^{\circ} 22^{\prime} \mathrm{W}$ (G. König-Langlo, personal communication, 2009). The mean ice draft was estimated from 2 upward-looking sonars (ULSs), which were deployed at the two northernmost moorings at $64^{\circ} \mathrm{S}$ and $66.5^{\circ} \mathrm{S}$. A third instrument, which was attached to the southernmost mooring at $69^{\circ} \mathrm{S}$, failed during its deployment. The ULS data processing was carried out by the method described by Strass (1998) with modifications introduced by Wolfgang Dierking (W. Dierking, personal communication, 2008). Connolley (2005) compared the Special Scanning Microwave Imager (SSM/I)-derived sea ice concentration in the Weddell Sea from the NASA Team and Bootstrap algorithms with upwardlooking sonar (ULS) data and found out that Bootstrap fits the ULS data much better than the Team algorithm. For this study we estimated the sea ice coverage at $64^{\circ} \mathrm{S}$ and $66.5^{\circ} \mathrm{S}$ on daily means of the available ULS data and compared them to the nearest pixel 
of SSM/I data derived from the Bootstrap algorithm (W. Dierking, personal communication, 2008). It has to be considered that the ULS footprint is approximately $10 \mathrm{~m}$, whereas the SSM /I data are provided on a $25-\mathrm{km}$ grid.

Chlorophyll $a$ was measured at every CTD station during R.V. Polarstern cruise ANT 23/2 (Fach et al., 2007). Water was taken at discrete depths $(5,20,30,50,100$ and $200 \mathrm{~m})$ from Niskin bottles of the CTD rosette and filtered onto GF/F glass microfibre filters (Whatman, $25 \mathrm{~mm}$ diameter), which were placed in plastic tubes filled with $10 \mathrm{ml}$ of $90 \%$ aqueous acetone and stored in a $-80^{\circ} \mathrm{C}$ freezer. After chlorophyll $a$ extraction for at least $24 \mathrm{~h}$, the plastic tubes were centrifuged $(700 \mathrm{~g})$ for $5 \mathrm{~min}$. The supernatant was used to measure Chl $a$ with a Turner 700D fluorometer. The discrete data set was supplemented by surface maps of chlorophyll $a$ concentration derived from Moderate Resolution Imaging Spectroradiometer (MODIS), which were acquired using the GESDISC Interactive Online Visualization and Analysis Infrastructure (Giovanni) as part of the NASA's Goddard Earth Sciences (GES) Data and Information Services Center (DISC) provided at http:// reason.gsfc.nasa.gov/OPS/Giovanni/ocean.aqua.shtml.

\section{Methods}

\subsection{MVBS computation}

The mean volume backscattering strength (MVBS) $S_{v}(\mathrm{~dB})$ was calculated from the recorded echo intensity $E$ (counts) after the version of the sonar equation presented by Deines (1999):

$\left.S_{V}=C+10 \log _{10}\left(\left(T_{x}+273.16\right) R^{2}\right)-L_{D B M}-P_{D B W}+2 \alpha R+K_{C}\left(E-E_{r}\right)\right)$

where $C$ is a system constant delivered by the manufacturer (which includes transducer and system noise characteristics and is $-159.1 \mathrm{~dB}$ for the Workhorse Longranger), $L_{D B M}$ the $10 \log _{10}$ (transmit pulse length/m), $P_{D B M}$ the $10 \log _{10}$ (transmit power $/ \mathrm{W}), T_{x}$ the temperature of the transducer $\left({ }^{\circ} \mathrm{C}\right), R$ the range along the beam to scatterers $(\mathrm{m}), \alpha$ the sound absorption coefficient of seawater $(\mathrm{dB} / \mathrm{m})$ and $K_{c}$ is a beam-specific scaling factor $\left(\mathrm{dB} /\right.$ count). The noise level $\left(E_{r}\right)$ of all four beams was determined from the minimum values of Received Signal Strength Indicator (RSSI) counts obtained in the remotest depth cell, when the sea surface was outside the ADCP range. Sound velocity $c$ and sound absorption coefficient $\alpha$ were considered variable with depth and time and calculated according to the UNESCO formula introduced by Fofonoff and Millard (1983) and computed after Francois and Garrison (1982) from an interpolation in time of 3 temperature and salinity profiles collected with the CTD probe, which were conducted at the mooring site at the beginning and the end of the deployment and during austral winter. Since CTD profiles from austral winter were not available for 2005 , we used a profile from June 2006.

\subsection{Estimation of migration velocity}

Under the assumption that upwelling or downwelling velocities are small, vertical velocity measured by the ADCP can be interpreted as the vertical swimming velocity of scattering organisms (Heywood, 1996). In order to analyse the seasonal variability of migration velocity, mean diel cycles of the ADCPderived vertical velocity were calculated for successive months. To obtain a better statistical significance of vertical velocity the diel cycles were averaged between 100 and $200 \mathrm{~m}$ depths. Since the velocity uncertainty of single-ping ADCP data is too large, averaging is used to reduce the measurement uncertainty to acceptable levels. The manufacturer indicates a single-ping uncertainty of 146 and $76 \mathrm{~mm} \mathrm{~s}^{-1}$ for their instruments configured in long-range mode with a bin length of either 8 or $16 \mathrm{~m}$. The statistical uncertainty of velocity measurements reduces to standard errors of $4.4 \mathrm{~mm} \mathrm{~s}^{-1}\left(146 /(\sqrt{30} \cdot \sqrt{6} \cdot \sqrt{6}) \mathrm{mm} \mathrm{s}^{-1}\right)$ and $0.7 \mathrm{~mm} \mathrm{~s}^{-1}\left(76 /(\sqrt{30} \cdot \sqrt{30} \cdot \sqrt{12}) \mathrm{mm} \mathrm{s}^{-1}\right)$ if we average over 1080 or 10,800 single-ping ensembles, respectively, which corresponds to the theoretical precision of $w$ averaged over a month and the depth range between 100 and $200 \mathrm{~m}$.

The identification and the analysis of DVM patterns, which are exhibited by different vertically migrating populations, demand a careful examination and intercomparison of both velocity and backscatter data. Therefore, mean daily cycles of $w$ and MVBS were calculated for successive 7-day periods at all stations and depth layers. According to the method first introduced by Luo et al. (2000), we also infer the vertical velocity from the "slope" velocity of individual MVBS contours. For the present study, the migrating layer of enhanced MVBS is fit by either a hyperbolic tangent function or a parabolic function. The vertical migration velocities were then calculated between each successive data point as the change in depth (m) per time (s). We define the downward migration phase of the parabolic fit as the time range that runs from the starting point to the vertex of the parabola, and the upward migration phase as that from the vertex to the endpoint. In the case of the hyperbolic tangent fit, we define the starting point and the endpoint as that depth where the change in depth of two successive data points exceeds $0.5 \mathrm{~m}$.

\section{Results}

\subsection{Hydrographic background}

The hydrographic survey covers parts of southeasterly limb of the Weddell Gyre and reveals two gateways, where water masses enter through the Lazarev Sea. Fig. 1a illustrates the horizontal currents in the depth range 150-200 m measured with the VM$\mathrm{ADCP}$ and averaged during periods when the ship was on station. The vectors show the highest velocities within the westward flowing Antarctic Coastal Current, which is confined to the Antarctic continental shelf slope and is associated with maximum velocities of about $40 \mathrm{cms}^{-1}$, and a probably topographically trapped west/southwest circulation around the northwestern edge of Maud Rise with maximum velocities of about $21 \mathrm{~cm} \mathrm{~s}^{-1}$. Hydrographic conditions of the upper $1000 \mathrm{~m}$ in the study area are illustrated by a section along the prime meridian from $60^{\circ} \mathrm{S}$ to $70^{\circ} \mathrm{S}$ (Figs. 1b-d). Figs. $1 \mathrm{~b}$ and c show that the open ocean surface layer consists mainly of less saline and (near)-freezing-point Antarctic surface water (ASW). Underneath the surface layer the Warm Deep Water (WDW) is found (Carmack and Foster, 1975), which is characterized by an intermediary temperature maximum of about $1{ }^{\circ} \mathrm{C}$ and a salinity maximum of about 34.7, which reveal its more northerly origin. Our results are in general agreement with previously reported hydrographic studies, e.g. those of Gordon and Huber (1995) and Bersch et al. (1992), who discussed bathymetric effects of the Maud Rise on stratification and circulation of the Weddell Gyre and showed a quasi-stationary pool of relatively warm WDW immediately west of this seamount, which entered this region along the northern slope of Maud Rise. At $69^{\circ} \mathrm{S}$ the surface layer deepens from $120 \mathrm{~m}$ towards the shelf break to more than $600 \mathrm{~m}$ near the Antarctic Slope Front, which separates the Winter Water and the Warm Deep Water from the colder and less saline shelf waters near the Antarctic continent (Fahrbach et al, 2004). Fig. 1b shows that all three moored ADCPs were placed in the inflow area of the WDW. This also holds for the $69^{\circ} \mathrm{S}$ mooring, which, while close to the ASF, was located in the WDW inflow for the whole deployment period, as revealed by the ADCP-measured temperature time series (not shown). 


\subsection{Characteristic patterns of the DVM}

In order to analyse and illustrate the characteristic patterns of the DVM in the MVBS distribution and the Doppler vertical velocity observed at the three mooring sites, we have selected four different weekly averaged diel patterns of the complete time series as examples: March 17-March 24 (autumnal equinox), June 16-June 23 (winter solstice), September 15-September 22 (vernal equinox) and December 8-December 12 (near summer solstice). The example weeks have been selected in order to represent characteristic days of the annual astronomical cycle (equinoxes and solstices). The MVBS distribution exhibits a variety of both distinct and diffuse bands of high backscatter, which indicate downward and upward migration of different mesopelagic species. In our analysis, we focus exemplarily on two bands, which were most frequently found between February and October 2005: (i) deep migrators-species migrating from the surface to below ADCP depth ( $>350 \mathrm{~m}$ ) by day to the surface at night and (ii) shallow migrators-species migrating from the surface to $300 \mathrm{~m}$ by day to the surface at night.

\subsubsection{Autumnal equinox}

Fig. 2a presents a typical example of these patterns taken from the period March 17 to March 24 at $66.5^{\circ} \mathrm{S}$ (sunrise: 05:58 GMT, sunset: $18: 15$ GMT, peak global radiation: $357 \mathrm{~W} \mathrm{~m}^{-2}$ ). Two hours before sunrise a group of "deep" migrators leaves the surface layer and descends quickly to a daytime residence below the ADCP depth. The scattering layer associated with these migrators is fit by a hyperbolic tangent function. Mean and maximum downward migration velocities estimated from the slope of this curve are -29 and $-79 \mathrm{mms}^{-1}$. A group of less concentrated and/or weaker scattering "slow" migrators descends from the surface layer to a depth of about $290 \mathrm{~m} 1 \mathrm{~h}$ later, reaches its residence depth at noon and ascends during the following $7 \mathrm{~h}$ to the surface layer with a mean velocity of about $10 \mathrm{mms}^{-1}$. The mean and maximum downward/upward migration velocities estimated from the slope of the fitted parabolic functions are -10 and $-20 \mathrm{~mm} \mathrm{~s}^{-1}$. The "deep" migrators ascend with mean and maximum velocities of 31 and $79 \mathrm{~mm} \mathrm{~s}^{-1}$ and reach their shallow nighttime residence $2 \mathrm{~h}$ after sunset. The deep and shallow migrators enhance the MVBS maximum at $\sim 50 \mathrm{~m}$ depth during the night. The lower panel presents the Dopplershift vertical velocity data for the same sampling period and shows two distinct bands of high downward velocities and upward velocities exceeding $\pm 30 \mathrm{~mm} \mathrm{~s}^{-1}$. These bands coincide with the steepest slopes of scattering layer of the "deep migrators". The "slow" migrators are however not detectable in the vertical velocity data, because the migration velocities are often indistinguishable from background velocities if we assume that the theoretical accuracy of daily $w$ averaged over 1 week is $28.7 \mathrm{~mm} \mathrm{~s}^{-1}\left(76 /(\sqrt{7}) \mathrm{mm} \mathrm{s}^{-1}\right)$. If we compare the motion of the slow and fast migrators with daily cycle of global radiation, it is clearly seen that both are highly correlated.

\subsubsection{Winter solstice}

While the patterns of the MVBS and the Doppler-shift vertical velocity were very similar during the months February-May at all three mooring sites, considerable differences occurred during the winter solstice. At $66.5^{\circ} \mathrm{S}$ two separate scattering layers can be seen in Fig. 2b (sunrise: 10:37 GMT, sunset: 13:25 GMT, peak global radiation: $\sim 1 \mathrm{~W} \mathrm{~m}^{-2}$ ). The mean and maximum slope velocities of the "deep" migrators are -22 and $-58 \mathrm{~mm} \mathrm{~s}^{-1}$, respectively. Only half an hour later "slow" migrators descend from the surface layer to a depth of about $250 \mathrm{~m}$ with mean and maximum descent velocities of -17 and $-34 \mathrm{mms}^{-1}$, respectively, reach their residence depth at noon
( $\sim 12: 00 \mathrm{GMT}$ ) and ascend during the following $3.5 \mathrm{~h}$ to the surface layer with mean and maximum velocities of about 17 and $34 \mathrm{~mm} \mathrm{~s}^{-1}$ and reach the surface $2 \mathrm{~h}$ after sunset. Maximum velocities estimated directly from ADCP vertical velocity data corresponding to the deep migrating layer are $30 \mathrm{~mm} \mathrm{~s}^{-1}$. Fig. $2 \mathrm{~b}$ also reveals a scattering layer at $\sim 85 \mathrm{~m}$ that persists during daylight hours with, however, reduced MVBS levels compared with the night.

At $64^{\circ} \mathrm{S}$ (sunrise: 09:55 GMT, sunset: 14:07 GMT, peak global radiation: $30 \mathrm{~W} \mathrm{~m}^{-2}$ ) the vertical distribution of the MVBS (Fig. 3a) reveals only one pattern of DVM, which is characterized by clearance of the upper water column. Clearance starts $3 \mathrm{~h}$ before sunrise and extends the deepest to more than $300 \mathrm{~m} 3 \mathrm{~h}$ later around noon ( $\sim 11: 30 \mathrm{GMT})$. Ascent occurs during the following $4.5 \mathrm{~h}$. The mean and maximum downward/upward migration velocities estimated from the slope of the fitted parabolic function are -18 and -35 and 19 and $36 \mathrm{~mm} \mathrm{~s}^{-1}$, respectively. This pattern coincides with a distinct band of elevated upward and downward Doppler vertical velocities of about $\pm 30 \mathrm{mms}^{-1}$.

Further south at $69^{\circ} \mathrm{S}$ the MVBS (peak global radiation: $\pm 1 \mathrm{~W} \mathrm{~m}^{-2}$ ) reveals one group of migrators (Fig. 3c), which during the darkest hours of the night forms part of a patchy layer of MVBS values around a depth of $\sim 170 \mathrm{~m}$. Although the sun stays under the horizon throughout the day, the DVM is still apparent with descent to a depth below $350 \mathrm{~m}$ starting at 9:30 GMT. Mean and maximum descent velocities estimated from the slope of the corresponding scattering layer are -17 and $-33 \mathrm{mms}^{-1}$. After reaching their deepest depth around noon, they ascend back during the following $3 \mathrm{~h}$ to a depth around $\sim 170 \mathrm{~m}$ with mean and maximum velocities of 17 and $33 \mathrm{~mm} \mathrm{~s}^{-1}$, respectively.

\subsubsection{Vernal equinox}

Fig. 2c suggests the presence of two distinct groups of migrators. The first group starts to descend $2 \mathrm{~h}$ before sunrise from the surface to below the ADCP with mean and minimum velocities of -29 and $-79 \mathrm{~mm} \mathrm{~s}^{-1}$, respectively. As the sun rises, a second group of migrators starts to clear the upper layers down to a depth of about $170 \mathrm{~m}$ with a mean descent velocity of $-10 \mathrm{~mm} \mathrm{~s}^{-1}$; it ascends during afternoon to reach its nighttime residence in the upper $50 \mathrm{~m} 1 \mathrm{~h}$ after sunset. Fig. 2c also reveals a scattering layer at $\sim 50 \mathrm{~m}$ that is maintained throughout the day.

\subsubsection{Summer solstice}

While diel migration patterns are still apparent in both backscatter and Doppler-shift vertical velocity data between February and October, the DVM ceased between mid-November and summer solstice at all three mooring sites. At $66.5^{\circ} \mathrm{S}$ (sunrise: 00:21 GMT, sunset: 23:34 GMT, peak global radiation: $783 \mathrm{~W}$ $\mathrm{m}^{-2}$ ) the distribution of the MVBS reveals an approximately vertically layered structure with highest values above $50 \mathrm{~m}$ depth and lowest values below $300 \mathrm{~m}$, superimposed by short-term temporal variations, but no indications of DVM (Fig. 2d). At $64^{\circ} \mathrm{S}$ (December 14, sunrise: 01:29 GMT, sunset: 22:21 GMT, peak global radiation: $826 \mathrm{~W} \mathrm{~m}^{-2}$ ) the scatterers appear distributed more evenly over the whole depth range throughout the day, and patterns of DVM (Fig. 3b) cannot be identified. Further south, at $69^{\circ} \mathrm{S}$ (peak global radiation: $357 \mathrm{~W} \mathrm{~m}^{-2}$ ), the scatterers appear distributed more evenly over the whole depth range with highest backscatter values at the uppermost layer.

\subsection{Seasonal variation of the DVM}

\subsection{1. $64^{\circ} \mathrm{S}$}

In order to analyse the seasonal variability of migration velocity, mean diel cycles of the ADCP-derived vertical velocity (averaged between 100 and $200 \mathrm{~m}$ depths) were calculated for 

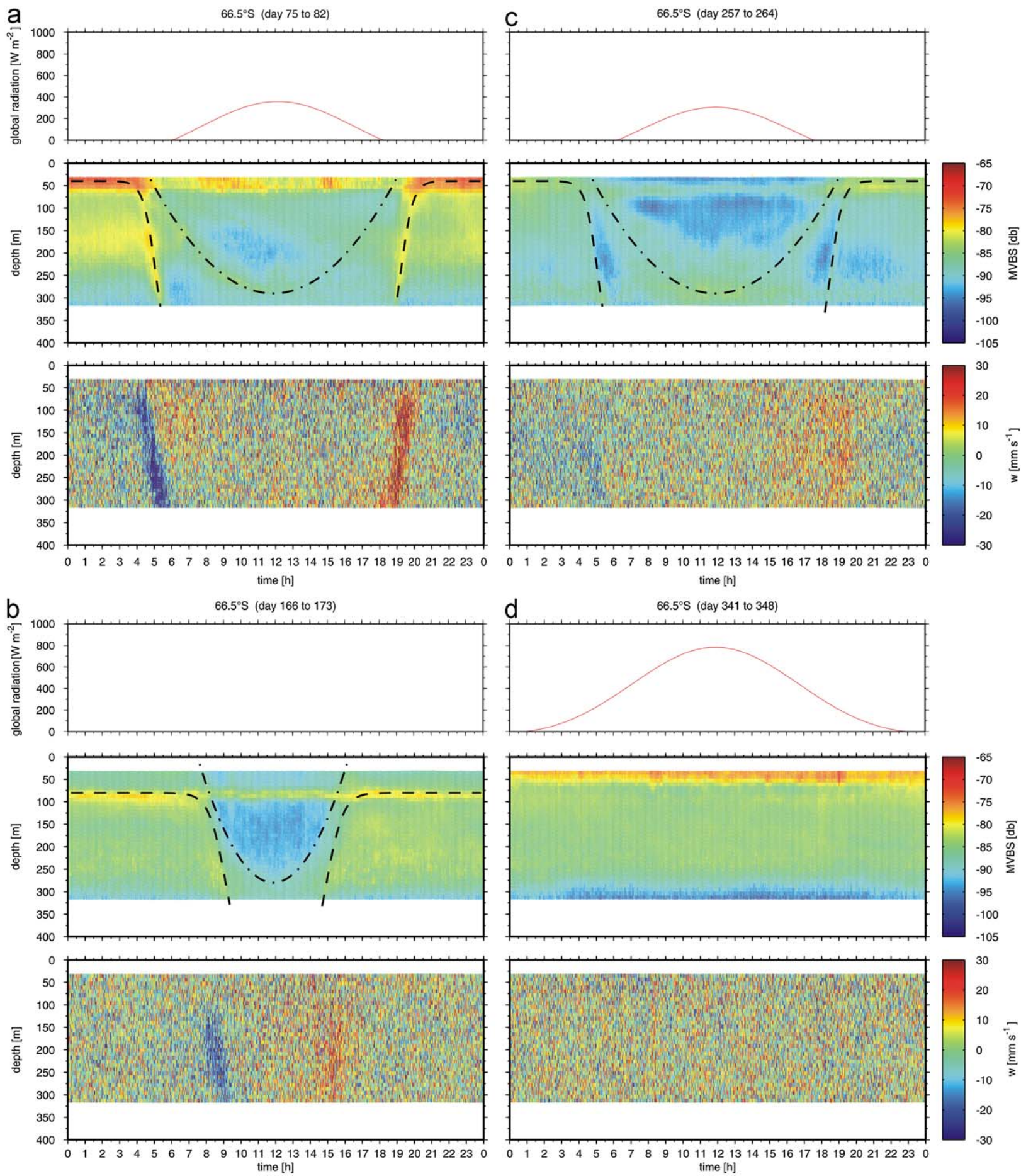

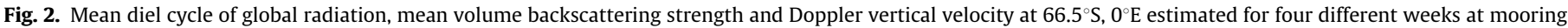

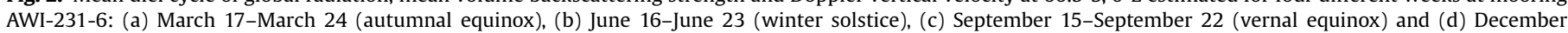

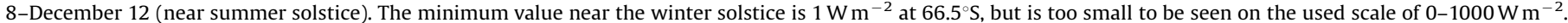
Dashed-dotted and dashed curves indicate volume scattering layers of "slow" and "deep" migrators, respectively.

successive months (Figs. 4a-c, Table 2). At the northernmost mooring site, a pronounced diel cycle persists for the months February-October 2005 (Fig. 4a). Downward motion occurs $-80.1 \pm 35.6 \mathrm{~min}$ before sunrise and upward motion $81.1 \pm$ 39.6 min after sunset (Table 2). Fig. 5a shows that the temporal distribution of these peaks is symmetric around noon and reveals a clear dependence on sun angle between February and October. However, ascent and descent velocities were higher during the phase of decreasing day length (February-June 2005) than those measured during the phase of increasing day length (JulyOctober). Starting in February 2005 the highest descent velocities of $-10 \mathrm{mms}^{-1}$ were observed at 04:00 GMT and the highest ascent velocities of $9 \mathrm{~mm} \mathrm{~s}^{-1}$ at 21:00 GMT (Fig. 4a, Table 2). In parallel with the shortening of day length between February and the winter solstice (June 21, 2005), the downward and upward migration peaks have been shifted by around $\pm 1 \mathrm{~h}$ per month. The 

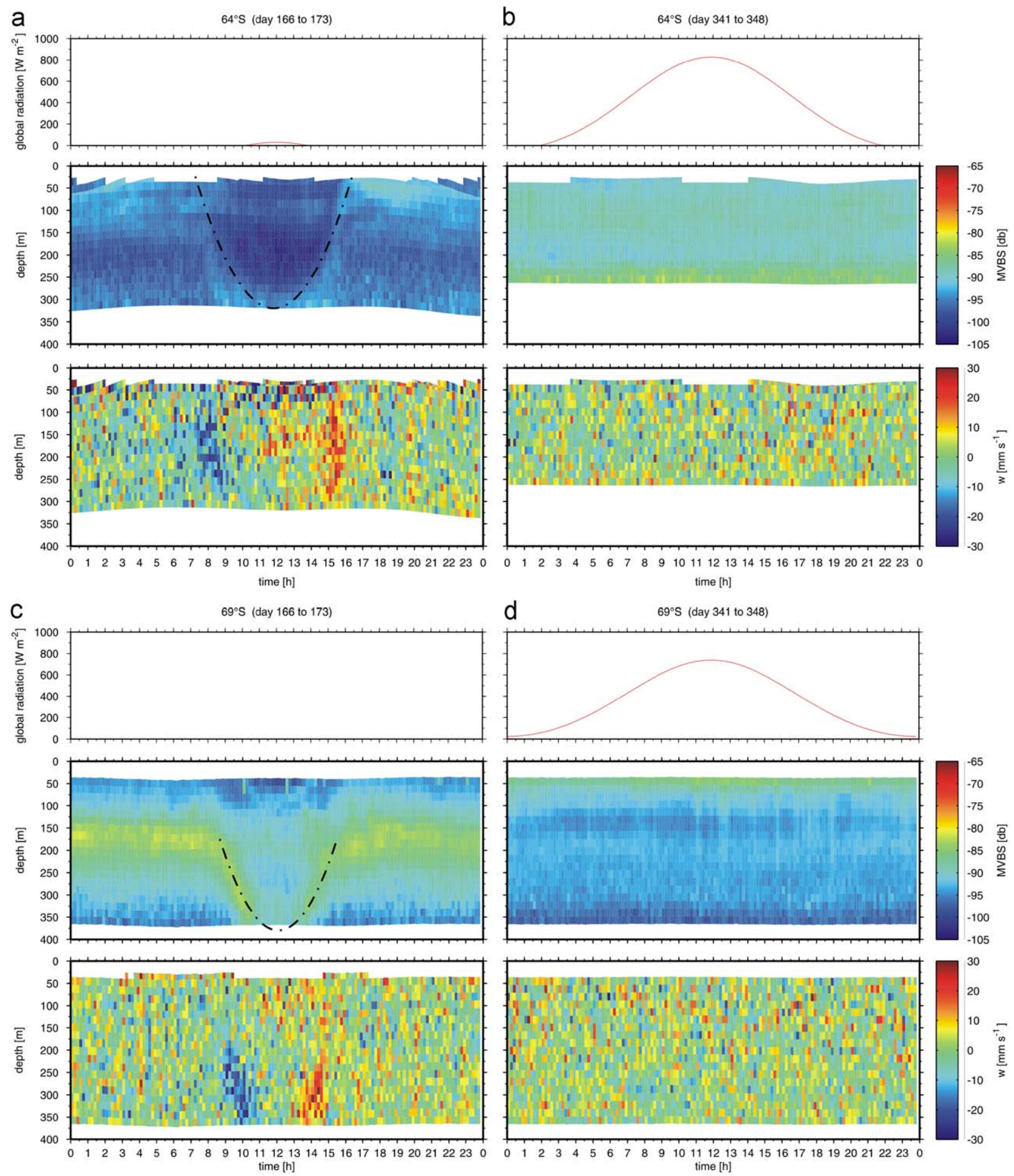

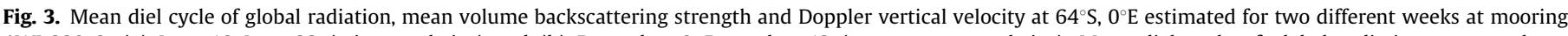

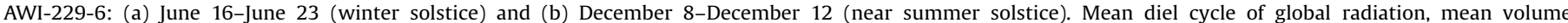

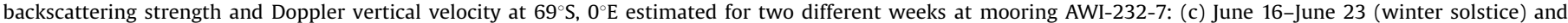

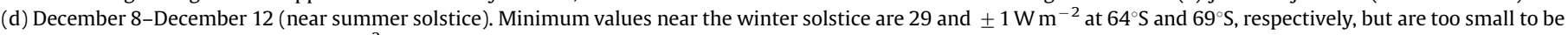
seen on the used scale of $0-1000 \mathrm{~W} \mathrm{~m}^{-2}$. Dashed-dotted curves indicate volume scattering layers.

highest ascent and descent velocities of 16 and $13 \mathrm{~mm} \mathrm{~s}^{-1}$, respectively, were observed in March 2005. Between July and October, the mean ascent and descent velocities ranged between 5 and $8 \mathrm{mms}^{-1}$, and -9 and $-7 \mathrm{~mm} \mathrm{~s}^{-1}$, respectively. A change of the vertical velocity pattern occurs from mid-November to midDecember. During this period, the diel vertical migration ceases.

\subsection{2. $66.5^{\circ} \mathrm{S}$}

The migration velocities observed at $66.5^{\circ} \mathrm{S}$ are very similar to those observed at $64^{\circ} \mathrm{S}$, with peaks distributed symmetrically around noon revealing a clear dependence on the sun angle between February and October (Fig. 5b). Starting in February 2005 the highest descent velocities of $-12 \mathrm{~mm} \mathrm{~s}^{-1}$ were observed at 
a

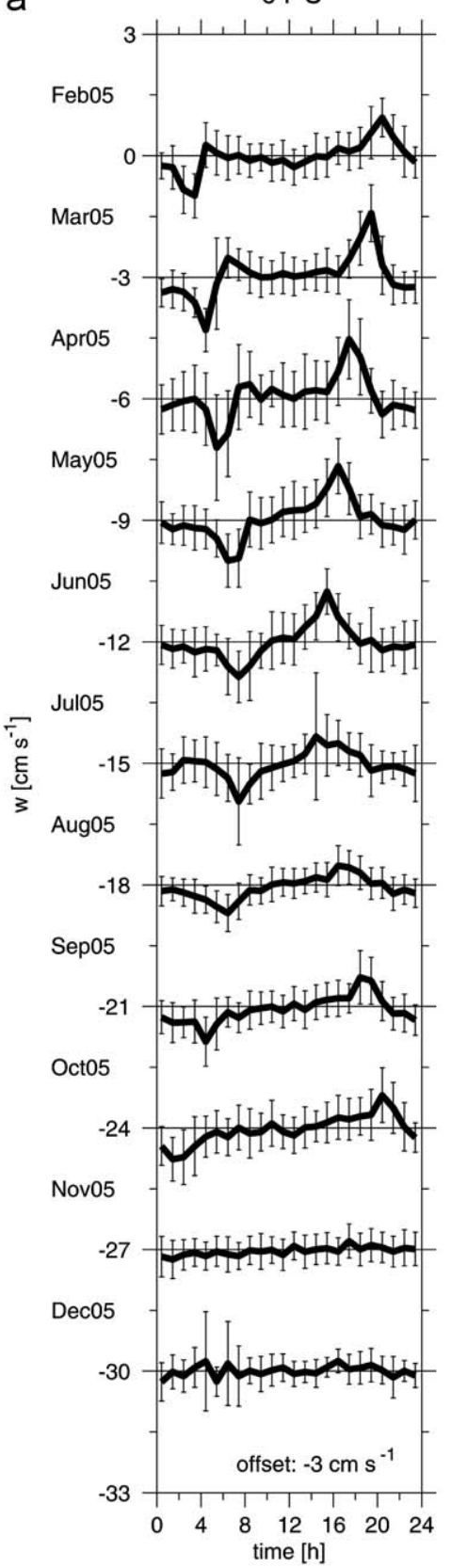

b

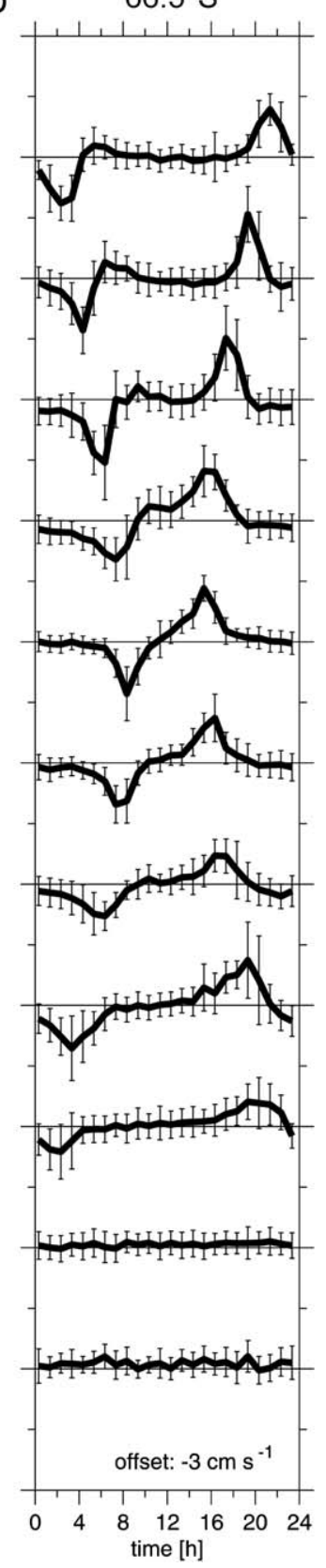

$69^{\circ} \mathrm{S}$

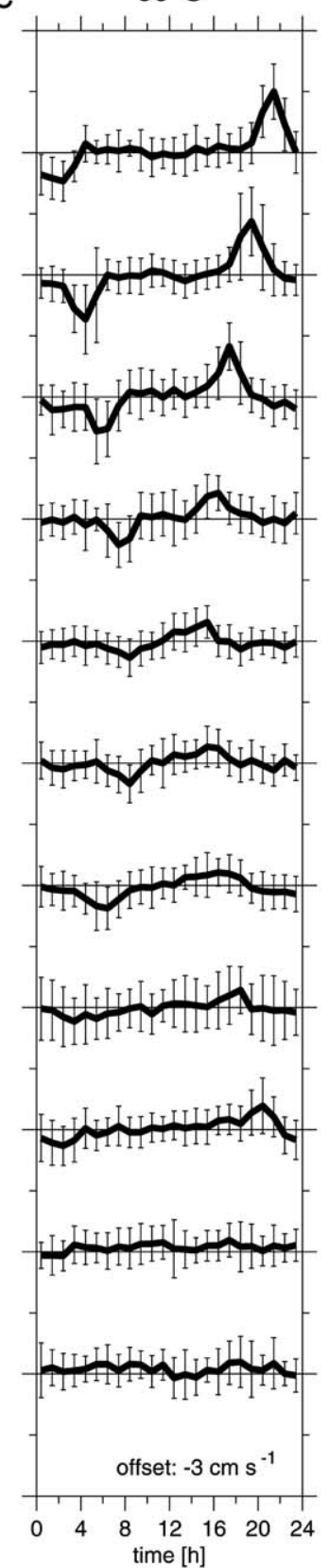

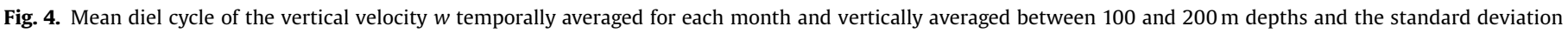
(as error bars) for all 3 moorings (a) AWI-229-6 (64 $\left.{ }^{\circ}, 0^{\circ} \mathrm{E}\right)$, (b) AWI-231-6 (66.5 $\left.{ }^{\circ} \mathrm{S}, 0^{\circ} \mathrm{E}\right)$ and (c) AWI-232-7 $\left(69^{\circ} \mathrm{S}, 0^{\circ} \mathrm{E}\right)$.

03:00 GMT and the highest ascent velocities of $12 \mathrm{~mm} \mathrm{~s}^{-1}$ at 22:00 GMT, i.e. an hour earlier and later, respectively, than at $64^{\circ} \mathrm{S}$ (Fig. 4b, Table 2). Downward motion occurs $-70.6 \pm 24.8 \mathrm{~min}$ before sunrise, and the upward motion occurs $94.9 \pm 44.6 \mathrm{~min}$ after sunset (Table 2). Corresponding to the shortening of day length between February and the winter solstice the downward and upward migration peaks shifted by around $\pm 1 \mathrm{~h}$ per month. The highest ascent and descent velocities of 16 and $-15 \mathrm{~mm} \mathrm{~s}^{-1}$, respectively, were observed in March/April 2005. Between July and October, the mean ascent and descent velocities ranged between 7 and $11 \mathrm{~mm} \mathrm{~s}^{-1}$, and -10 and $-7 \mathrm{~mm} \mathrm{~s}^{-1}$, respectively. In agreement with the observation made at $64^{\circ} \mathrm{S}$, a change of the vertical velocity pattern occurs from mid-November to midDecember, when the diel vertical migration ceases.

\subsection{3. $69^{\circ} \mathrm{S}$}

In February 2005 at $69^{\circ} \mathrm{S}$, the highest descent velocities of $-8 \mathrm{~mm} \mathrm{~s}^{-1}$ were observed at 03:00 GMT and the highest ascent velocities of $16 \mathrm{~mm} \mathrm{~s}^{-1}$ at 22:00 GMT (Fig. 4c, Table 2). With the shortening of day length between February and end of May the downward and upward migration peaks shifted by around $\pm 1 \mathrm{~h}$ per month. For this period the downward motion starts $-91.5 \pm 34.9 \mathrm{~min}$ before sunrise and the upward motion starts $107.3 \pm 46.2 \mathrm{~min}$ after sunset (Table 2 ). However, DVM persists through mid-winter, from the end of May until early July, when the sun does not rise above the horizon. The highest ascent and descent velocities of 16 and $-10 \mathrm{~mm} \mathrm{~s}^{-1}$, respectively, were observed in February/March 2005. While the descent and ascent velocities observed between February and April 2005 are 
Table 2

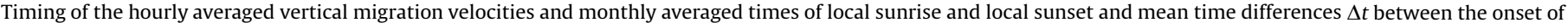
downward migration and sunrise and between upward migration and sunset, respectively.

\begin{tabular}{|c|c|c|c|c|c|c|c|}
\hline Latitude & Month & Hour & Sunrise & $\begin{array}{l}\text { Monthly mean of daily max. } \\
\text { descent velocity }\left(\mathrm{mm} \mathrm{s}^{-1}\right)\end{array}$ & Hour & Sunset & $\begin{array}{l}\text { Monthly mean of daily max. } \\
\text { ascent velocity }\left(\mathrm{mm} \mathrm{s}^{-1}\right)\end{array}$ \\
\hline \multirow[t]{12}{*}{$64^{\circ} \mathrm{S}$} & Feb. & 04:00 & $04: 22$ & $-9.9 \pm 5.6$ & 21:00 & 20:03 & $9.3 \pm 4.8$ \\
\hline & Mar. & 05:00 & 05:45 & $-13.1 \pm 5.3$ & 20:00 & $18: 30$ & $16.2 \pm 6.8$ \\
\hline & Apr. & 06:00 & $07: 15$ & $-12.7 \pm 12.7$ & $18: 00$ & $16: 44$ & $14.6 \pm 9.8$ \\
\hline & May & 07:00 & 08:42 & $-9.6 \pm 6.8$ & $17: 00$ & $15: 11$ & $13.3 \pm 6.9$ \\
\hline & Jun. & 08:00 & 09:48 & $-8.9 \pm 6.5$ & $16: 00$ & $14: 13$ & $12.5 \pm 5.5$ \\
\hline & Jul. & 08:00 & 09:11 & $-9.3 \pm 10.8$ & $15: 00$ & $15: 02$ & $6.7 \pm 15.7$ \\
\hline & Aug. & 07:00 & $08: 23$ & $-7.0 \pm 4.5$ & $17: 00$ & $15: 47$ & $4.9 \pm 4.9$ \\
\hline & Sep. & 05:00 & $06: 11$ & $-8.3 \pm 6.2$ & $19: 00$ & $17: 40$ & $7.7 \pm 6.3$ \\
\hline & Oct. & 02:00 & $04: 24$ & $-7.9 \pm 5.4$ & 21:00 & $19: 10$ & $7.9 \pm 6.9$ \\
\hline & Nov. & & $02: 41$ & a & & $20: 52$ & a - \\
\hline & Dec. & & $01: 40$ & a & & $22: 05$ & a \\
\hline & & \multicolumn{2}{|c|}{$\Delta \mathrm{t}=-80.1 \pm 35.6 \mathrm{~min}$} & $\begin{array}{l}\text { Mean max. descent velocity } \\
\text { (Feb.-Oct.) }\left(\mathrm{mm} \mathrm{s}^{-1}\right) 9.6 \pm 2.1\end{array}$ & \multicolumn{2}{|c|}{$\Delta \mathrm{t}=81.1 \pm 39.6 \mathrm{~min}$} & $\begin{array}{l}\text { Mean max. ascent velocity } \\
\left(\text { Feb.-Oct.) }\left(\mathrm{mm} \mathrm{s}^{-1}\right) 10.3 \pm 3.9\right.\end{array}$ \\
\hline \multirow[t]{12}{*}{$66.5^{\circ} \mathrm{S}$} & Feb. & 03:00 & $04: 14$ & $-11.8 \pm 4.0$ & $22: 00$ & $20: 10$ & $12.2 \pm 3.6$ \\
\hline & Mar. & 05:00 & $05: 43$ & $-12.9 \pm 5.8$ & 20:00 & $18: 32$ & $15.6 \pm 7.4$ \\
\hline & Apr. & 07:00 & $07: 23$ & $-14.7 \pm 1.0$ & $17: 00$ & $16: 36$ & $15.3 \pm 7.8$ \\
\hline & May & 08:00 & 09:03 & $-9.5 \pm 5.5$ & $16: 00$ & $14: 50$ & $12.2 \pm 4.3$ \\
\hline & Jun. & 09:00 & $10: 27$ & $-13.1 \pm 7.0$ & $16: 00$ & $13: 34$ & $13.3 \pm 3.3$ \\
\hline & Jul. & 08:00 & 09:36 & $-10.1 \pm 4.6$ & $17: 00$ & $14: 37$ & $11.4 \pm 5.9$ \\
\hline & Aug. & 07:00 & $08: 40$ & $-7.9 \pm 3.6$ & $17: 00$ & $15: 31$ & $7.3 \pm 3.9$ \\
\hline & Sep. & 04:00 & $06: 13$ & $-10.1 \pm 7.7$ & $20: 00$ & $17: 38$ & $11.3 \pm 9.4$ \\
\hline & Oct. & 03:00 & $04: 16$ & $-6.6 \pm 6.8$ & $20: 00$ & $19: 18$ & $6.8 \pm 7.8$ \\
\hline & Nov. & & $02: 16$ & a & & $21: 17$ & a - \\
\hline & Dec. & & $02: 35$ & a & & $19: 56$ & a \\
\hline & & \multicolumn{2}{|c|}{$\Delta \mathrm{t}=-70.6 \pm 24.8 \mathrm{~min}$} & $\begin{array}{l}\text { Mean max. descent velocity } \\
\text { (Feb.-Oct.) }\left(\mathrm{mm} \mathrm{s}^{-1}\right)-10.7 \pm 2.6\end{array}$ & \multicolumn{2}{|c|}{$\Delta \mathrm{t}=94.9 \pm 44.6 \mathrm{~min}$} & $\begin{array}{l}\text { Mean max. ascent velocity } \\
\text { (Feb.-Oct.) }\left(\mathrm{mm} \mathrm{s}^{-1}\right) 11.7 \pm 3.1\end{array}$ \\
\hline \multirow[t]{12}{*}{$69^{\circ} \mathrm{S}$} & Feb. & 03:00 & $04: 11$ & $-7.8 \pm 4.3$ & $22: 00$ & $20: 13$ & $15.9 \pm 6.2$ \\
\hline & Mar. & $05: 00$ & 05:39 & $-10.4 \pm 9.0$ & $20: 00$ & $18: 36$ & $12.9 \pm 8.7$ \\
\hline & Apr. & 06:00 & 07:38 & $-9.2 \pm 8.5$ & $18: 00$ & $16: 21$ & $12.9 \pm 5.3$ \\
\hline & May & 08:00 & 09:52 & $-7.1 \pm 6.0$ & $17: 00$ & $14: 01$ & $6.7 \pm 4.1$ \\
\hline & Jun. & 09:00 & $\mathrm{N} / \mathrm{A}$ & $-4.0 \pm 4.5$ & $16: 00$ & $\mathrm{~N} / \mathrm{A}$ & $4.7 \pm 4.0$ \\
\hline & Jul. & 09:00 & $10: 22$ & $-5.0 \pm 4.6$ & $16: 00$ & $13: 34$ & $4.1 \pm 5.0$ \\
\hline & Aug. & 07:00 & $09: 14$ & $-5.4 \pm 5.3$ & $17: 00$ & $14: 49$ & $3.2 \pm 3.4$ \\
\hline & Sep. & 04:00 & $06: 16$ & $-3.2 \pm 5.7$ & $19: 00$ & $17: 35$ & $4.4 \pm 5.7$ \\
\hline & Oct. & 03:00 & 04:00 & $-4.3 \pm 4.4$ & $20: 00$ & $19: 34$ & $6.1 \pm 6.7$ \\
\hline & Nov. & & $03: 34$ & a & & $18: 34$ & a $--a$ \\
\hline & Dec. & & $\mathrm{N} / \mathrm{A}$ & a & & $\mathrm{N} / \mathrm{A}$ & a \\
\hline & & \multicolumn{2}{|c|}{$\Delta \mathrm{t}=-91.5 \pm 34.9 \mathrm{~min}$} & $\begin{array}{l}\text { Mean max. descent velocity } \\
\text { (Feb.-Oct.) }\left(\mathrm{mm} \mathrm{s}^{-1}\right)-6.3 \pm 2.5\end{array}$ & \multicolumn{2}{|c|}{$\Delta t=107.3 \pm 46.2 \mathrm{~min}$} & $\begin{array}{l}\text { Mean max. ascent velocity } \\
\text { (Feb.-Oct.) }\left(\mathrm{mm} \mathrm{s}^{-1}\right) 7.9 \pm 4.7\end{array}$ \\
\hline
\end{tabular}

a Daily mean vertical velocity is close to zero.

comparable to those obtained at $64^{\circ}$ and $66.5^{\circ}$ S, they decrease by more than a half during the next 6 months. In agreement with the observation made at $64^{\circ}$ and $66.5^{\circ} \mathrm{S}$, diel vertical migration ceases from mid-November to mid-December.

\subsection{Seasonal variation of mean volume backscattering strength}

The time series of vertical integrals of MVBS profiles (Fig. 6) suggest a seasonal pattern in volume backscattering strength in the upper $50-300 \mathrm{~m}$ of the water column $\left(\mathrm{MVBS}_{50-300 \mathrm{~m}}\right)$, particularly at the mooring sites $64^{\circ} \mathrm{S}$ and $66.5^{\circ} \mathrm{S}$. Measured backscattering strength declined at all sites $\left(64^{\circ} \mathrm{S}, 66.5^{\circ} \mathrm{S}\right.$ and $69^{\circ} \mathrm{S}$ ) during autumn towards winter, with a temporal re-increase in May/June at $66.5^{\circ} \mathrm{S}$ and $69^{\circ} \mathrm{S}$. The magnitude of decline and pattern of seasonal re-increase in $\mathrm{MVBS}_{50-300 \mathrm{~m}}$ were very different between the locations. The largest decline was at $64^{\circ} \mathrm{S}$, where the difference between summer maximum and winter minimum amounted to nearly $12 \mathrm{~dB}$, translating to a 16-fold decline in the linear domain. At this northerly mooring site, the minimum in $\mathrm{MVBS}_{50-300 \mathrm{~m}}$ was observed around the winter solstice, and $\mathrm{MVBS}_{50-300 \mathrm{~m}}$ increased again almost immediately thereafter. Compared with $64^{\circ} \mathrm{S}$, the seasonal re-increase in volume backscattering strength $(50-300 \mathrm{~m})$ was delayed to spring at the mooring sites south to Maud Rise, but was less clear at $69^{\circ} \mathrm{S}$.

\subsection{Environmental factors influencing DVM}

\subsubsection{Light}

The patterns of DVM at $64^{\circ} \mathrm{S}, 66.5^{\circ} \mathrm{S}$ and $69^{\circ} \mathrm{S}$ reveal a strong relationship to the astronomical daylight cycles. Fig. 5 shows that the ascent and descent velocities peak symmetrically around noon and correlate with the sun angle between February and October In contrast with the symmetry of diel migration maxima, the annual cycle of vertical migration speeds is not symmetrical around winter solstice. At all three mooring sites the vertical migration speeds are generally higher during the period of decreasing day length from end of summer to mid-winter than during the period of increasing day length, spring to early summer. From mid-November to mid-December, until the end of the time series, the zooplankton communities ceased vertical migration completely. Between November 01, 2005, and 
a

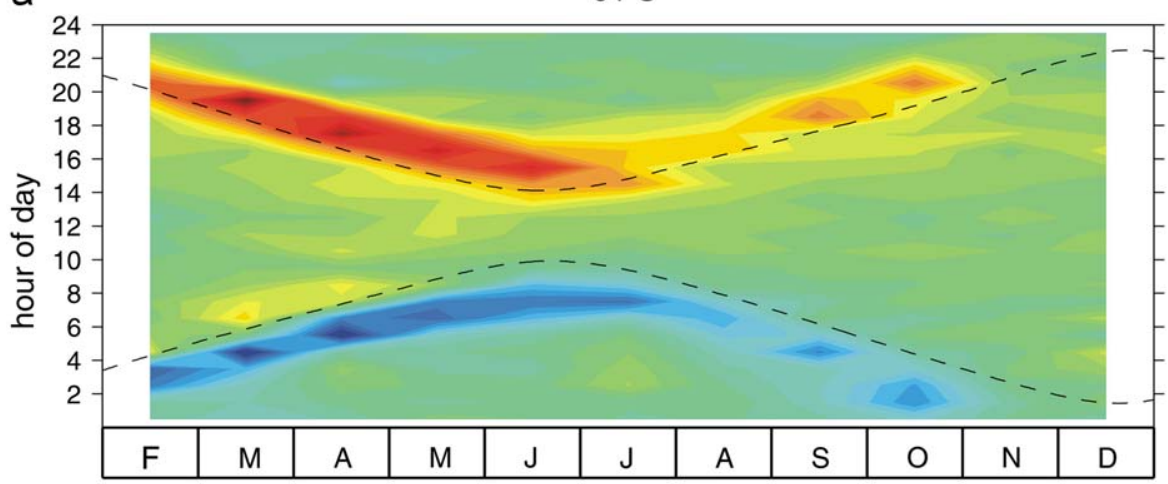

$b_{24}$

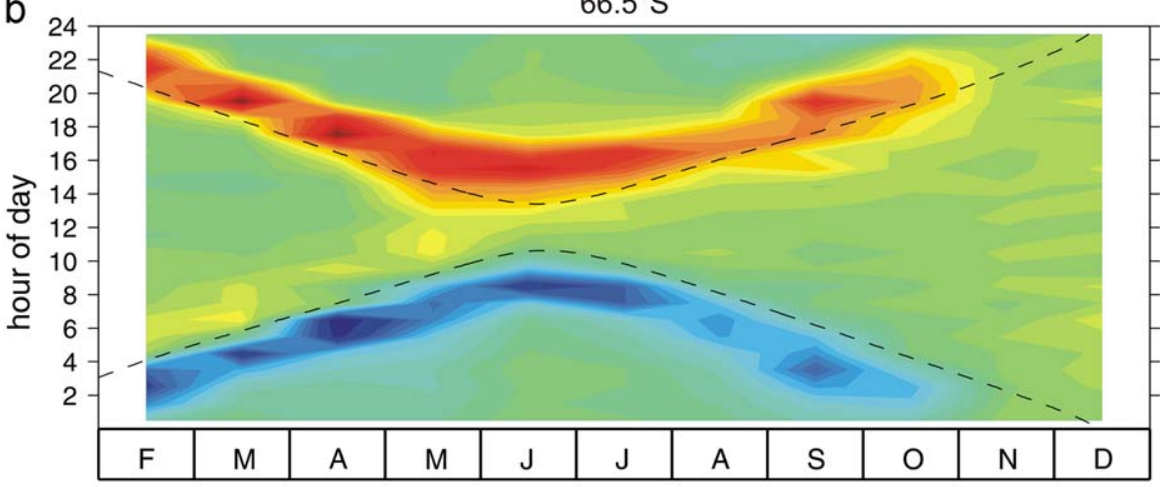

$69^{\circ} \mathrm{S}$

C

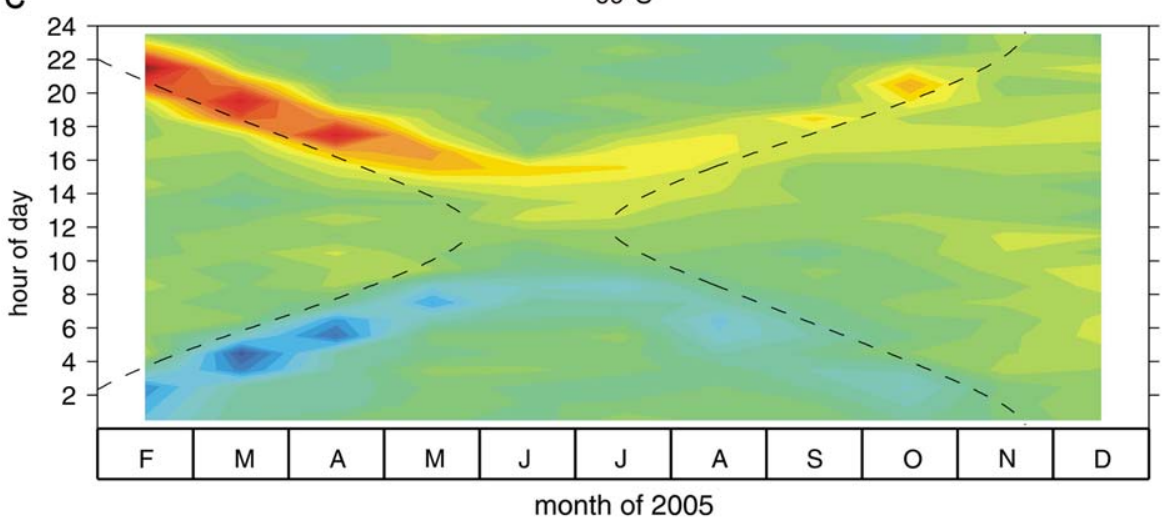

1.5

1

$0.5 \div$

0

$-0.5$

$-1$

$-1.5$

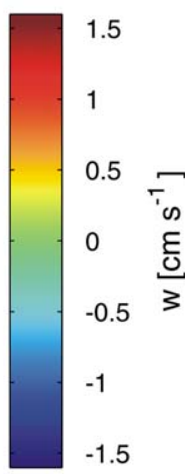

1.5

1

0.5

$0 \quad \frac{E}{3}$

$-0.5$

$-1$

$-1.5$

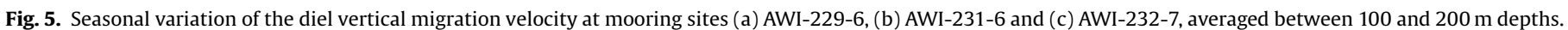
Contour intervals are $0.1 \mathrm{~cm} \mathrm{~s}^{-1}$. Dashed lines show the times of local sunrise and sunset.

December 19, 2005, the day length increased from 15.3 to $20.0 \mathrm{~h}$ at $64^{\circ} \mathrm{S}$, from 15.8 to $22.1 \mathrm{~h}$ at $66.5^{\circ} \mathrm{S}$ and from 16.3 to $24.0 \mathrm{~h}$ (austral midsummer) at $69^{\circ} \mathrm{S}$. During midsummer at high latitudes, when the sun does not set, relative light levels do not change rapidly within the daily cycle. However, the day length in early November, when the DVM came to a halt, was approximately the same as in mid-February at the beginning of the time series, when the zooplankton communities performed their DVM with high speeds.

\subsubsection{Ice coverage and phytoplankton}

Time series of the ULS-derived daily mean ice draft and ice coverage, which were obtained at $64^{\circ} \mathrm{S}$ and $66.5^{\circ} \mathrm{S}$ (Figs. 7a-d), show that the mooring positions were ice covered between July 9 and December 16 and between May 31 and December 15, respectively. The sea ice cover at $64^{\circ} \mathrm{S}$ and $66.5^{\circ} \mathrm{S}$ started to decay in early November and decreased further until mid-
December. The beginning of decay of sea ice cover roughly corresponds with the time when the zooplankton start to suspend their diel vertical migration (compare with Fig. 5). The sea ice formation during June and July in contrast had no obvious influence on the DVM speeds or MVBS patterns. The chlorophyll a concentration, which was measured at the end of the mooring deployment along the prime meridian, indicates elevated phytoplankton abundance in the upper $40 \mathrm{~m}$ and a pronounced phytoplankton bloom of up to $4.2 \mathrm{mg} \mathrm{m}^{-3}$ chlorophyll between $65^{\circ} \mathrm{S}$ and $67^{\circ} \mathrm{S}$ (Fig. 8a). This phytoplankton bloom developed during the decay of sea ice; its development from November until December and its areal extent is shown in Figs. 8d and e.

\section{Discussion}

The seasonal variability of diel vertical migration in the Southern Ocean has rarely been studied before. Thus, our high 

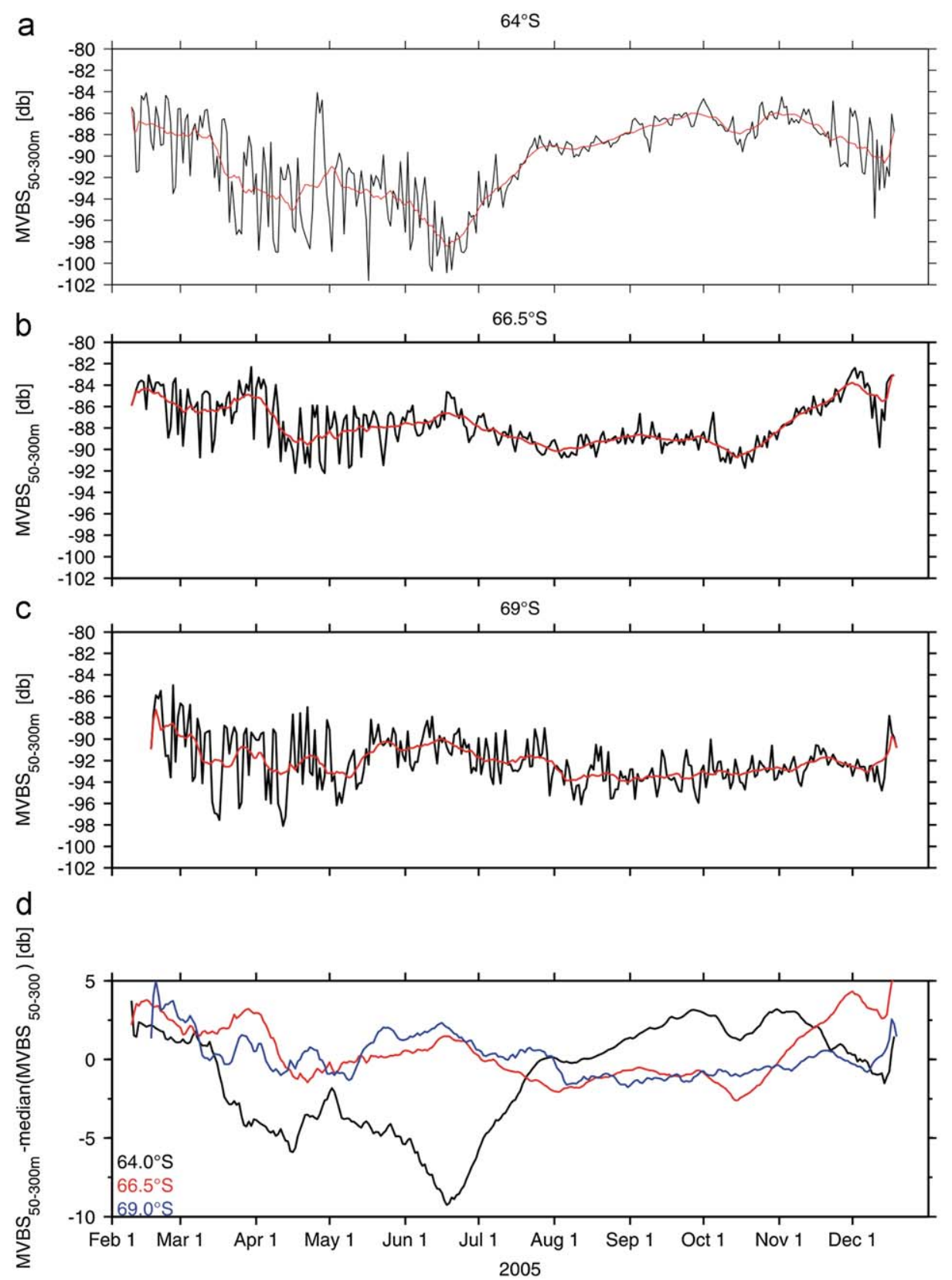

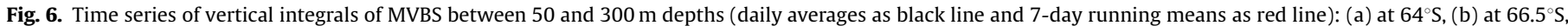
(c) at $69^{\circ} \mathrm{S}$ and (d) the difference of 7-day running MVBS means and the MVBS-median in the depth range 50-300 $\mathrm{m}$.

temporal resolution ADCP data sets obtained from 3 locations distributed along a meridional transect are unique for this area. The patterns of DVM at $64^{\circ} \mathrm{S}, 66.5^{\circ} \mathrm{S}$ and $69^{\circ} \mathrm{S}$ reveal a close relationship to the astronomical daylight cycles (Figs. 2 and 3 ) and a strong correlation with timing of dawn and dusk for the period February-October, 2005 (Figs. 5a-c). Although it is generally accepted that light plays a role in controlling the daily timing of migrations (for reviews, see Forward, 1988 and Ringelberg, 1995), specific characteristics of changing downwelling light field, e.g. light intensities or its relative rate of change, which acts as the trigger to cue these migrations in mesopelagic species, are still under discussion (Frank and Widder, 1997; Cohen and Forward, 2002). However, while our results support hypotheses for light as the most important exogenous cue for diel vertical migration in general, we cannot exactly specify which aspects of the environmental light field serve as cue because of a lack of further information on the migrators themselves and the light field within the water.

Our data show that the vertical migration behaviour of zooplankton changes in late spring/early austral summer at all 3 mooring sites. While DVM persists from February to October, the zooplankton communities cease their migration beginning late October/early November. During this transition period, the light environment changes from a true day-night contrast to one of continuous sunlight. The observed halt of DVM around October/ November could have been caused either by fewer animals choosing to migrate or by a decrease in animal abundance. However, the time courses of water-column-integrated volume backscattering strength in the upper $50-300 \mathrm{~m}$ (Fig. 6) do not indicate a decrease of animal abundance at this time of the year. There is evidence of a decrease of animal abundance somewhat later, from early November until mid-December at $64^{\circ} \mathrm{S}, 66.5^{\circ} \mathrm{S}$ 


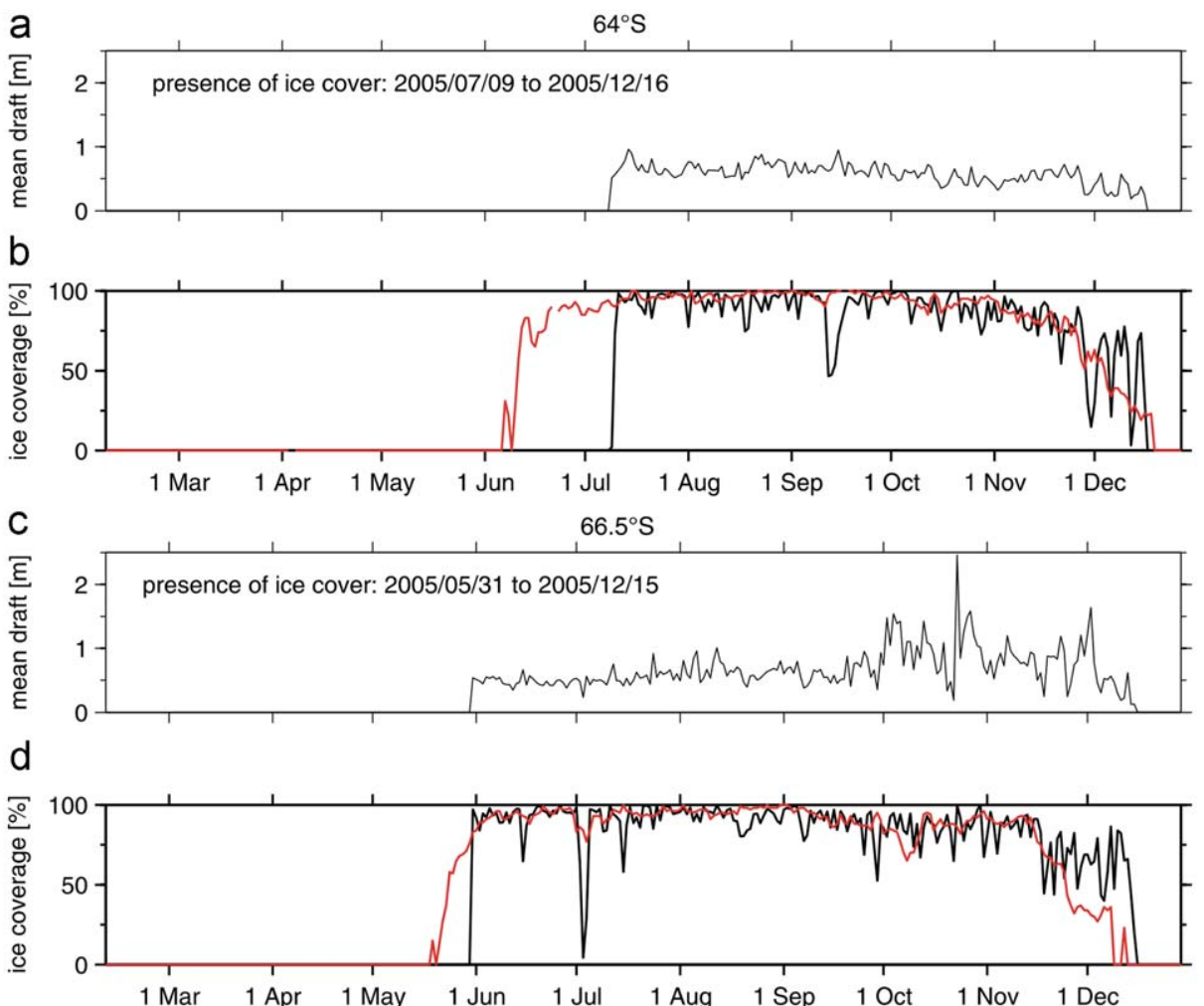

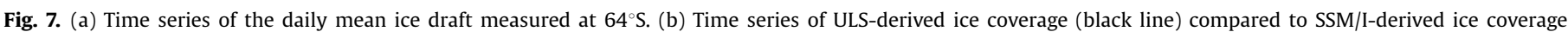

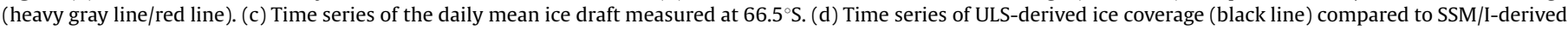
ice coverage (heavy gray line/red line). (For interpretation of the references to colour in this figure legend, the reader is referred to the web version of this article.)

and $69^{\circ} \mathrm{S}$, but animal abundance rather increases from midOctober to November. Therefore, the halt of DVM late spring/early summer cannot be explained by a sudden lack of animals.

Since the change in light intensity is believed to trigger the DVM, some authors have assumed that zooplankton do not migrate under the midnight sun (e.g. Bogorov, 1946; Buchanan and Haney, 1980; Blachowiak-Samolyk et al., 2006). This view is corroborated by our results for the early summer period, November-mid-December (Figs. 2d and 3), when DVM apparently did not occur and the observed zooplankton communities remained in the uppermost $50 \mathrm{~m}$ at $66.5^{\circ} \mathrm{S}$ and $69^{\circ} \mathrm{S}$, but not so for the late summer month February, when the astronomical light cycle was almost the same as in early November and high vertical migration speeds were recorded. Moreover, it is also not corroborated by our time series at $64^{\circ} \mathrm{S}$ (Fig. 3b), where the sun is under the horizon for $\sim 4 \mathrm{~h}$ even at summer solstice but diel vertical migration nevertheless ceased.

However, in a recent study Cottier et al. (2006) demonstrated that the absence of a synchronised migration pattern does not necessarily presume total absence of animal migration, and thus a distinction must be made between synchronized vertical migrations of populations and unsynchronized vertical migration of individuals. They used both net tows and ADCP-derived backscatter intensities to analyse the vertical migration of zooplankton in an Arctic fjord at $79^{\circ} \mathrm{N}$ during the transition period from continuous illumination to alternating light and dark. During the weeks of continuous illumination, there was no net displacement of zooplankton apparent in the backscatter data, but the Doppler vertical velocity showed a continuous net downward movement in the surface layers and a net upward movement at depth, which was interpreted by the authors as unsynchronized vertical migrations by individuals. Cottier et al. (2006) suggested that the animals were adopting a foray-type behaviour under con- tinuous light conditions with active swimming up and down to minimize the time spent in the high-risk, food-rich surface layers. In periods with a true nighttime a strong and synchronized vertical migration took place.

We conclude from our MVBS and Doppler velocity data that synchronized vertical migration ceased from early November until at least mid-December at all three mooring sites (see Figs. 2d, 3b and d). However, we find no evidence for unsynchronized vertical migration in our vertical velocity data. Unfortunately, our time series do not cover a complete annual cycle and thus do not include the summer period from mid-December to mid-February to reveal when the zooplankton resumed their DVM. In this context, recent studies have shown that even during the midnight sun period some copepod species underwent diel vertical migration under sea ice (e.g. Fortier et al., 2001; Tanimura et al., 2008). Fortier et al. (2001) suggested that even small diel change in light intensity appearing under sea ice during continuous illumination would be sufficient to stimulate copepod migration.

While most studies of DVM at higher latitudes have focussed on the period of midnight sun or the transition between Arctic summer and autumn (Fortier et al., 2001; Blachowiak-Samolyk et al., 2006; Cottier et al, 2006; Falk-Petersen et al., 2008), Berge et al. (2009) presented acoustic data from two coastal locations in Svalbard (Kongsfjorden and Rijpfjorden at $79^{\circ} \mathrm{N}$ and $80^{\circ} \mathrm{N}$, respectively), which demonstrate a synchronized DVM behaviour of zooplankton that continues throughout Arctic winter. Their findings are corroborated by our results from the Southern Hemisphere, where synchronous DVM continued at $69^{\circ} \mathrm{S}$ throughout austral winter and thus disproves the classic paradigm of Arctic and Antarctic marine ecosystems that DVM slows down or ceases during the polar night.

Phytoplankton, which provides the food supply for herbivorous zooplankton, is restricted to the upper, photic layer of the water 
a
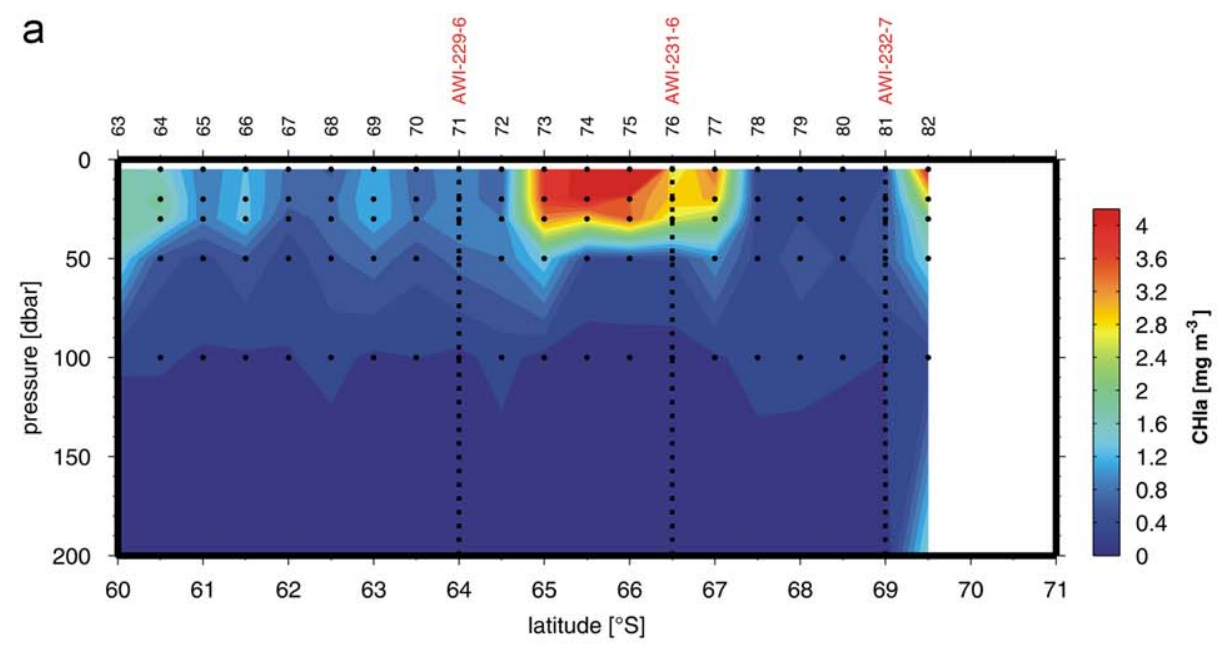

b

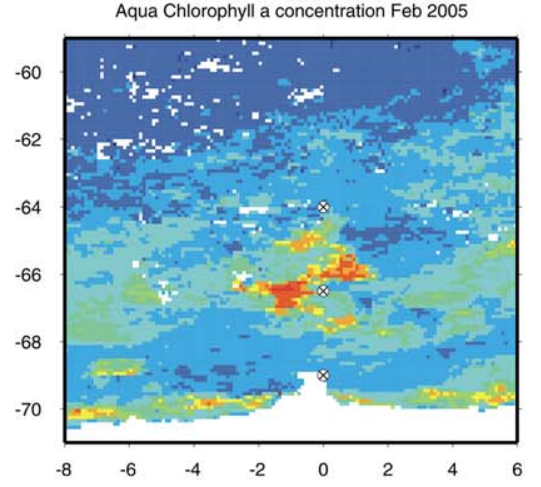

C Aqua Chlorophyll a concentration Mar 2005

d
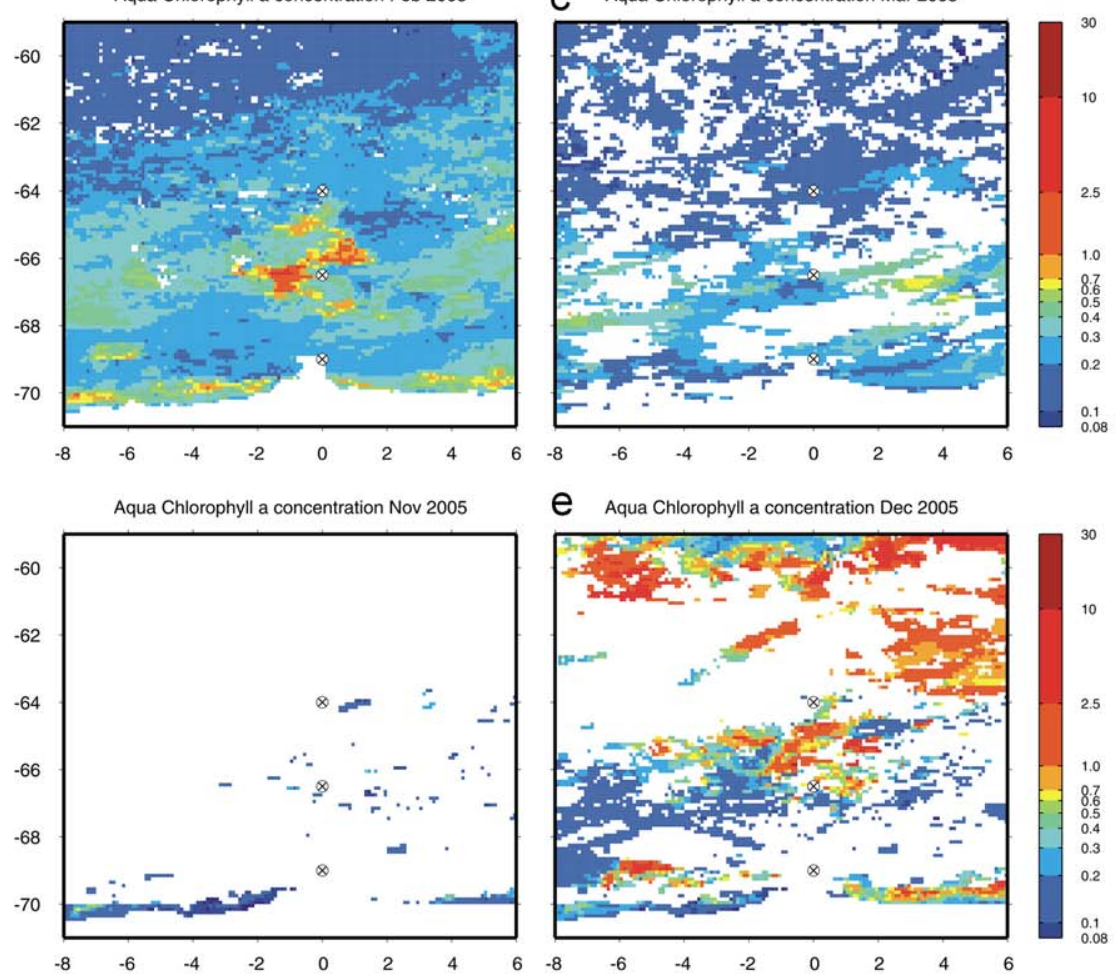

e Aqua Chlorophyll a concentration Dec 2005

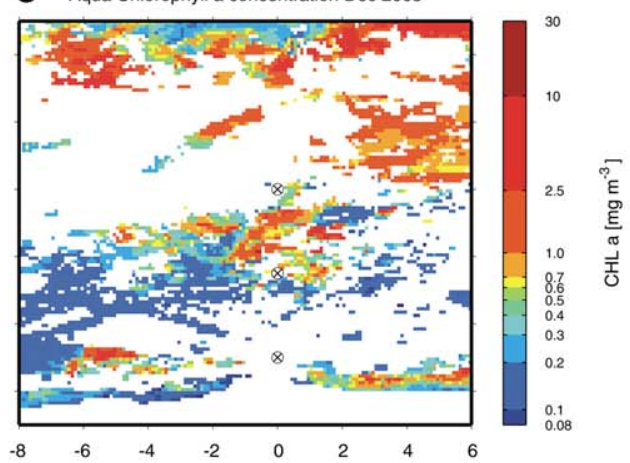

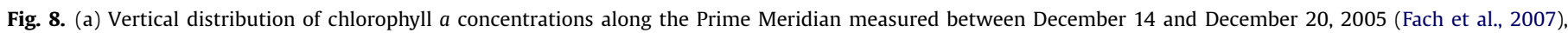

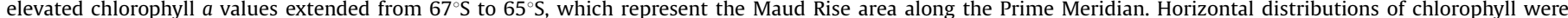

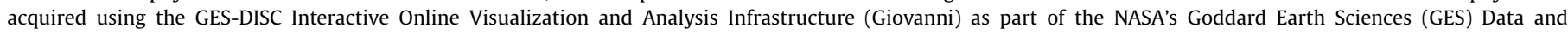

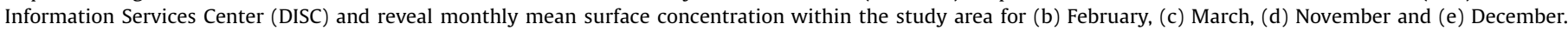
The map shows the decay and the new development of an algae bloom near Maud Rise in 2005.

column and declines rapidly with depth. While the meridional differences in temporal development and in the strength of the observed bloom (Fig. 8a) apparently did not have a clear effect on the timing of DVM suspension (Fig. 5), the MVBS patterns (6d) revealed the strongest shift of the zooplankton vertical distribution towards the surface layer at $66.5^{\circ} \mathrm{S}$, where the phytoplankton bloom in December was most pronounced. However, the monthly mean surface chlorophyll $a$ concentration derived from satellite remote sensing, illustrated in Figs. $8 \mathrm{~b}$ and c, reveals the presence of a phytoplankton bloom at the same location, in the region southeast of Maud Rise, in February 2005 with decaying levels lasting until March 2005. That bloom apparently did not stimulate the dominant zooplankton communities to stay close to the surface (Fig. 5a) without performing a DVM (Fig. 4).
While considerable differences between the 3 mooring sites are evident if the records from particular weeks are compared (Figs. 2 and 3), the time series on the whole are dominated by very similar patterns of diel displacements of the MVBS signatures and of the vertical migration velocities (Figs. 4 and 5). An explanation for the observed similarity or dissimilarity can be found in the regional hydrographic regime. Figs. 1a-d show that all 3 moorings, although spread over a meridional distance of more than $550 \mathrm{~km}$, are located within the same general hydrographic regime, the inflow of Warm Deep Water (WDW), which is associated with the southeastern limb of the Weddell Gyre. The WDW, characterized by temperatures higher than $0{ }^{\circ} \mathrm{C}$, occupies the majority of the water column above $1000 \mathrm{~m}$ except the surface $100-200 \mathrm{~m}$, where Antarctic Surface Water (ASW) dominates. The major 
hydrographic differences between the 3 mooring sites are related to the advection routes of the WDW. Whereas the 2 northernmost moorings, AWI-229 and AWI-231, are influenced by a current that is topographically steered around the northwestern flank of Maud Rise, the southernmost mooring, AWI-232, is influenced by an eastward current associated with the Antarctic continental slope and the so-called Antarctic Slope Front, ASF. The ASF, which separates the Warm Deep Water from the colder and less saline shelf waters near the Antarctic continent, flows in an easterly direction with the Antarctic Coastal Current, has been suggested as also acting as a boundary of certain zooplankton species (e.g. Scharek et al., 1994; Pagès and Schnack-Schiel, 1996). The temperature time series obtained from the ADCP at the southernmost mooring (not shown here), however, reveals that the instrument was located within the WDW inflow for the whole deployment period.

One aspect in which the 2 northernmost mooring sites are more similar to each other than to the southernmost mooring is the vertical migration speeds. For the first 9 months of the deployment period, during which diel migration maxima could be identified, the overall mean maximum descent velocities are $-9.6 \pm 2.1$ and $-10.7 \pm 2.6 \mathrm{~mm} \mathrm{~s}^{-1}$, and the maximum ascent velocities are $10.3 \pm 3.9$ and $11.7 \pm 3.1 \mathrm{~mm} \mathrm{~s}^{-1}$ at $64^{\circ} \mathrm{S}$ and $66.5^{\circ} \mathrm{S}$, respectively, compared with a maximum descent velocity of $-6.3 \pm 2.5 \mathrm{~mm} \mathrm{~s}^{-1}$ and a maximum ascent velocity of $7.9 \pm 4.7 \mathrm{~mm} \mathrm{~s}^{-1}$ at $69^{\circ} \mathrm{S}$. It is unclear if the slower migration speeds at the southernmost site are related to the proximity of the ASF and thus possibly to the presence of different zooplankton assemblages, or if it is related to the fact that the southernmost site experiences the smallest amplitude of diel changes of solar elevation because it is located south of the Polar Circle and thus is the only one of the 3 mooring sites that experiences the polar night (May 31-July 13) during winter and the polar day (November 24-January 20) during summer.

The MVBS distribution exhibits a variety of both distinct and diffuse bands of high backscatter, which indicate downward and upward migrations of different mesopelagic species. In this paper we have been laying emphasis on two different bands, which were most persistently found during the period February-October: The first group of so-called "deep migrators" descends $0.5-3 \mathrm{~h}$ before local sunrise below the ADCP $(>300 \mathrm{~m})$ with a mean slope velocity ranging between -20 and $-31 \mathrm{~mm} \mathrm{~s}^{-1}$ and ascends to the surface with a mean slope velocity ranging between 20 and $34 \mathrm{~mm} \mathrm{~s}^{-1} 0.5-3 \mathrm{~h}$ after sunset. The second group of so-called "shallow migrators" descends $0.5-1.5 \mathrm{~h}$ before local sunrise with a mean slope velocity ranging between -6 and $-20 \mathrm{~mm} \mathrm{~s}^{-1}$ and ascends to the surface with a mean slope velocity ranging between 6 and $21 \mathrm{~mm} \mathrm{~s}^{-1} 0.5-1.5 \mathrm{~h}$ after sunset. The maximum hourly mean vertical migration speeds estimated from the measured vertical component of ADCP velocity ( -15 to $16 \mathrm{~mm}$ $\mathrm{s}^{-1}$ ) were on average lower than those estimated from the slope of the scattering layer $\left(-34\right.$ to $\left.31 \mathrm{~mm} \mathrm{~s}^{-1}\right)$. This discrepancy is consistent with that found by other studies made by Plueddemann and Pinkel (1989), Heywood (1996), Luo et al. (2000) and Tarling et al. (2001). These discrepancies arise from the two different estimation methods. While the vertical velocities estimated by fitting a curve to the undulating sound scattering layers represent an estimate of the speed of the fastest coherently migrating scatterers alone, the ADCP Doppler measurements reflect an intensity-weighted sum of all scatterer velocities within the water volume and space/time windows used for averaging, which encompass animals that move incoherently. The estimated ADCP migration velocities are within the range reported in previous studies.

Fischer and Visbeck (1993) deployed moored ADCPs for 1 year in the central Greenland Sea $\left(73^{\circ} 22^{\prime} \mathrm{N}-75^{\circ} 04^{\prime} \mathrm{N}\right)$ and measured peak ascent and descent velocities of about $\pm 15 \mathrm{~mm} \mathrm{~s}^{-1}$. Strong seasonal variations in the DVM were evident, and both the timing and migration amplitude changed with daylight as the season progressed. In summer and during the polar night the migration became very weak and was detectable only in the displacement of scattering layers. However, our data provide evidence that DVM at the high latitudes of the Southern Ocean ceases in early summer, but persists during times when the sun is under the horizon during the polar night.

Record and de Young (2006) analysed the backscatter and velocity data from moored ADCPs obtained on the Newfoundland Shelf with focus on the Northeast Newfoundland Shelf and coastal embayments $\left(47^{\circ} 25^{\prime} \mathrm{N}-49^{\circ} 28^{\prime} \mathrm{N}, 52^{\circ} 52^{\prime} \mathrm{W}-54^{\circ} 24^{\prime} \mathrm{W}\right)$. Based on their ADCP data derived from 12 deployments during 1999 and 2001 the mean and maximum ascent velocities ranged between 9 and 25 and 11 and $38 \mathrm{~mm} \mathrm{~s}^{-1}$, and the mean and minimum descent velocities ranged between -9 and -23 and -15 and $-26 \mathrm{~mm} \mathrm{~s}^{-1}$, respectively. Vertical migration was highly persistent at all mooring sites throughout the deployments. The authors showed that the migration responded to changes in light intensity and water temperature.

Pinot and Jansá (2001) measured ADCP migration speeds of about $\pm 30-40 \mathrm{~mm} \mathrm{~s}^{-1}$ in the Ibiza Channel, Mediterranean Sea $\left(39^{\circ} 06^{\prime} \mathrm{N}\right)$, during a 1 -year experiment. They showed that two distinct patterns of DVM indicate that there are two main communities of zooplankton responding to changes in irradiance. Jiang et al. (2007) used the ADCP measurements obtained at the Bermuda Testbed Mooring, which is located southeast of Bermuda $\left(31^{\circ} 43^{\prime} \mathrm{N}\right)$, and estimated the maximum vertical velocity, which occurred in spring, as $54 \mathrm{~mm} \mathrm{~s}^{-1}$. Diel vertical migration patterns for the summer period were evident, but vertical migration speeds were slower than in spring. In fall, there was a persistent, strong subsurface maximum layer during night, and in winter, DVM was less pronounced compared with other seasons. The differences in the pattern of vertically integrated mean volume backscatter strength $\left(\mathrm{MVBS}_{50-300 \mathrm{~m}}\right)$ at our mooring sites north and south of Maud Rise cannot be solely explained as forced by differences in light climate or ice coverage. Other factors certainly have also played a role. The northerly mooring was located within a southwest circulation, which seems to be trapped by the topography of Maud Rise. This region is reported to differ from other regions of the Lazarev Sea in terms of spawning pattern of copepods, their stage composition and vertical distribution, e.g. during winter (Bathmann et al., 1993; Spiridonov et al., 1996). The seasonal migration behaviour of the local zooplankton community potentially involves both the direct response of predominantly herbivore species to, e.g., regional differences in primary production and the response of carnivorous zooplankton to the vertical distribution of their prey organisms. Thus, the regional differences between seasonal pattern in $\mathrm{MVBS}_{50-300 \mathrm{~m}}$ between $64^{\circ} \mathrm{S}$ and the mooring sites south of Maud Rise might be explained without invoking strong differences in zooplankton and nekton compositions. Seasonal changes in overall volume backscattering strength in the upper water column can be caused by individual growth, recruitment and mortality as well as by seasonal up- and downward migrations of backscattering organisms into or out of the ADCP range. Among the Southern Ocean zooplankton, a lot is known about the seasonal vertical migration behaviour of copepods. Most of them migrate seasonally, however, and show distinct species- and stage-specific and regional differences in migration amplitude and timing (Atkinson et al., 1992; Ward et al., 1997; Schnack-Schiel, 2001). Since there were no net hauls of plankton near the moorings during their deployment period, we can only speculate about the species composition of zooplankton whose migration is documented by our measurements. Diel vertical migration has been observed in diverse zooplankton 


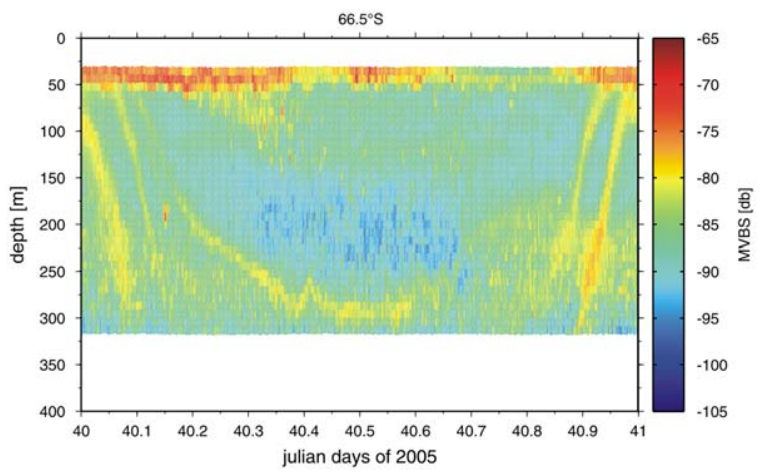

Fig. 9. Diel cycle of the mean volume backscattering strength estimated for February 10, 2005 at mooring AWI-231-6; highlighting five different bands of high backscatter.

and nekton taxa in the Southern Ocean, as in other parts of the world ocean. DVM behaviour is shown by crustacean and noncrustacean zooplankton such as salps and pteropods (Nishikawa and Tsuda, 2001; Hunt et al., 2008). However, diel vertical migration is a very common behaviour especially in crustaceans, observed in Antarctic krill, E. superba (Siegel, 2005), and other euphausiids like Thysanoessa macrura (Nordhausen, 1994), amphipods like Themisto gaudichaudi (Everson and Ward, 1980) and most Southern Ocean copepods (Atkinson et al., 1992) including small species (e.g. Ctenocalanus citer) and large species (e.g. Rhincalanus gigas). Copepods are very weak scatterers of sound (Stanton and Chu, 2000), and small or less abundant species should have contributed insignificantly to the acoustic backscattering. The acoustic record likely reflects the migration behaviour of non-predatory zooplankton as well as the interaction of larger predatory zooplankton with smaller, less acoustically detectable prey organisms. Small pelagic fish (e.g. myctophids), which prey upon zooplankton, possibly have also contributed to the acoustic backscattering. In view of the observed backscattering levels, however, they should have occurred at low abundances (Benoit-Bird and $\mathrm{Au}, 2001$ ).

Our measurements with the highest resolution (at $66.5^{\circ} \mathrm{S}$ ) prior to averaging reveal a variety of both distinct and diffuse bands of high backscatter. As an example, the MVBS record measured on February 10, 2005 (Fig. 9) indicates five distinct bands of high backscatter, which move up and down on a diel cycle. This suggests that at least five different mesopelagic species or their development stages participated in the DVM. Taking into account a possible co-occurrence of different species within the same band of high backscatter and the existence of animals that are less visible in the acoustic data, it is likely that more than just two species, evident at first glance from the two most persistent bands of deep and shallow migrators, have performed diel vertical migration during at least some time of the year.

\section{Summary and conclusion}

Three timeseries of mean volume backscattering strength (MVBS) and vertical velocity, each 10 months long and obtained at different locations, have been recorded by moored ADCPs in the Lazarev Sea. These time series have enabled the first analysis of the daily vertical zooplankton migration and its seasonality and regional variability in the Southern Ocean.

While detailed signatures in our MVBS records indicate that several zooplankton or nekton species performed a synchronous diel vertical migration, two groups were the most prominent: deep migrators with a vertical migration range between the upper $50 \mathrm{~m}$ and below ADCP depth $(>350 \mathrm{~m}$ ) and shallow migrators with a vertical migration range between the upper $50 \mathrm{~m}$ and somewhat less than $300 \mathrm{~m}$. The deep migrators started their descent $0.5-3 \mathrm{~h}$ before sunrise and reached their maximum downward vertical migration speed $0.5-2 \mathrm{~h}$ before sunrise; their ascent started $0.5-3 \mathrm{~h}$ after sunset, and they reached their maximum upward vertical migration speed $0.5-2 \mathrm{~h}$ after sunset. The shallow migrators started their descent $0.5-1.5 \mathrm{~h}$ before sunrise (and reached their maximum downward vertical migration speed 0.5 $1.5 \mathrm{~h}$ before sunrise); their ascent started $0.5-1.5 \mathrm{~h}$ after sunset, and they reached their maximum upward vertical migration speed $0.5-1.5 \mathrm{~h}$ after sunset. To this extent, our results corroborate earlier findings that support hypotheses for light as the most important exogenous cue for diel vertical migration.

While the DVM was symmetric around local noon, the annual modulation of the DVM was clearly asymmetric around winter solstice or summer solstice. In contrast with many previous studies in other regions, DVM at our observation sites persisted throughout winter, even at the highest latitude exhibiting the polar night. The highest vertical migration speeds occurred in late summer and autumn (February-April) and then decreased gradually. A marked change in the migration behaviour occurred in late spring (late October/early November), when the DVM ceased completely. This halt of synchronous DVM occurred when the light environment changed from a clear day/night contrast to one of continuous illumination at the southernmost mooring and to a dim-light short night of 3-4h duration at the northernmost mooring. DVM was resumed during summer. In February, when the lengths of day and night were similar to those at the end of October/early November when DVM came to a halt before, DVM was resumed with vertical amplitudes and migration speeds approaching their annual maximum. In conclusion, whereas the DVM itself is tightly coupled to the times of sunrise and sunset, the annual modulation of the DVM cannot be explained by the annual astronomical cycle of solar irradiance.

To explain the annual asymmetry of the diel vertical migration we propose the following tentative hypothesis. The gradual decrease in vertical velocity amplitude during the period from late summer/early autumn to late winter/early spring is possibly the result of two effects: (1) reduced food availability related to the decreased primary production in the surface photic zone and (2) gradual consumption of energy reserves of migrators in the course of winter; interestingly, the highest vertical migration speeds were recorded during the months February-April, i.e. from end of summer to early autumn, when the energy reserves can reasonably be assumed filled to their annual maximum, and the slowest migration speeds were recorded during the months August-October, i.e. from end of winter to early spring, when the energy reserves are likely consumed after the food-poor winter period. The subsequent suspension of DVM after early November is possibly the consequence of another combination of causes: (1) increased availability of food in the surface mixed layer provided by the phytoplankton spring bloom that forms during the sea ice melt and (2) vanishing diel variation of the threat from visually oriented predators during the quasi-continuous illumination during the polar and subpolar summer, which means there is no obvious best or worst daytime in terms of visual predation threat for the zooplankton to visit the surface layers. Under those early summer conditions, continuous feeding to meet the nutritional demands for growth and reproduction can be an advantage. Staying alternatively at greater depth below the phytoplankton containing surface layer to escape visual predation throughout the polar or subpolar summer and thus miss the seasonal blooming of phytoplankton is certainly not a good option for the zooplankton. In fact can the depths of zooplankton accumulation during the period of suspended DVM be related to the stage of the phytoplankton bloom? The MVBS record from the 
mooring at $66.5^{\circ} \mathrm{S}$, where a pronounced phytoplankton bloom had developed until mid-December, revealed a marked accumulation of zooplankton in the top tens of metres. At $69^{\circ} \mathrm{S}$, where an edge of the phytoplankton spring bloom was located in mid-December, the MVBS record showed a slight increase of the zooplankton concentrations towards the surface. At $64^{\circ} \mathrm{S}$ in contrast, where no phytoplankton bloom was present in December, the MVBS record indicated an increase of zooplankton abundance with depth. A reproduction-following shift within the zooplankton assemblage towards the earliest and young development stages with limited swimming abilities certainly contributes also to the suspension of DVM, and the smaller/younger developmental stages would likely profit from reduced visual conspicuousness to potential visual predators. However, as soon as the young of the year have attained strength and can afford diel vertical migrations when the energy reserves have been built up during the course of summer, DVM is resumed to take advantage of predator avoidance even when the diel amplitude of solar irradiance is still small; DVM of the offspring possibly also stimulates vertical migration of their predators.

Further time series, which cover the complete seasonal cycle and preferentially more than just 1 year, are, however, needed to resolve when the zooplankton resume their DVM. They are also needed to confirm that the annual asymmetry is a robust feature of the diel vertical migration behaviour in the Lazarev Sea/ Southern Ocean.

\section{Acknowledgements}

This work forms part of the joint project LAKRIS (Lazarev Sea Krill Study) funded by the German Federal Ministry of Education and Research (Bundesministerium für Bildung und Forschung, BMBF). Harry Leach and Harald Rohr contributed substantially to the collection of the hydrographic data set. Wolfgang Dierking and Hannelore Witte provided the upward-looking sonar (ULS) data. Gert König-Langlo supplied the global radiation data measured at the Neumayer station within the Baseline Surface Radiation Network (BSRN), which is managed by the World Radiation Monitoring Center (WRMC) hosted by the Division of Climate Sciences at the Alfred Wegener Institute for Polar and Marine Research in Bremerhaven, Germany. We gratefully acknowledge the support provided by the captain, officers and crew of the R/V Polarstern. We also appreciate helpful comments provided by the three anonymous reviewers.

\section{References}

Arrigo, K.R., Thomas, D.N., 2004. Large scale importance of sea ice biology in the Southern Ocean. Antarctic Science 16, 471-486.

Atkinson, A., Ward, P., Williams, R., Poulet, S.A., 1992. Diel vertical migration and feeding of copepods at an oceanic site near South Georgia. Marine Biology 113, 583-593.

Bathmann, U.V., Makarov, R.R., Spiridonov, V.A., Rohardt, G., 1993. Winter distribution and overwintering strategies of the Antarctic copepod species Calanoides acutus, Rhincalanus gigas and Calanus propinquus (Crustacea, Calanoida) in the Weddell Sea. Polar Biology 13, 333-346.

Benoit-Bird, K.J., Au, W.W.L., 2001. Target strength measurements of animals from the Hawaiian mesopelagic boundary community. Journal of the Acoustical Society of America 110, 812-819.

Berge, J., Cottier, F., Last, K.S., Varpe, Ø., Leu, E., Søreide, J., Eiane, K., Falk-Petersen, S., Willis, K., Nygård, H., Vogedes, D., Griffiths, C., Johnsen, G., Lorentzen, D. Brierley, A.S., 2009. Diel vertical migration of Arctic zooplankton during the polar night. Biology Letters 5, 69-72.

Bersch, M., Becker, G.A., Frey, H., Koltermann, K.-P., 1992. Topographic effects of the Maud Rise on the stratification of the Weddell Gyre. Deep-Sea Research 39, 303-331.

Blachowiak-Samolyk, K., Kwasniewski, S., Richardson, K., Dmoch, K., Hansen, E., Hop, H., Falk-Petersen, S., Mouritsen, L.T., 2006. Arctic zooplankton do not perform diel vertical migration (DVM) during periods of midnight sun. Marine Ecology Progress Series 308, 101-116.
Bogorov, B.G., 1946. Peculiarities of diurnal vertical migration of zooplankton in polar seas. Journal of Marine Research 6, 25-32.

Brierley, A.S., Ward, P., Watkins, J.L., Goss, C., 1998. Acoustic discrimination of Southern Ocean zooplankton. Deep-Sea Research II 45, 1155-1173.

Buchanan, C., Haney, J.F., 1980. Vertical migrations of zooplankton in the Arctic: a test of the environmental controls. In: Kerfoot, W.C. (Ed.), Evolution and Ecology of Zooplankton Communities. University Press of New England, Hanover, NH, pp. 69-79.

Carmack, E.C., Foster, T.D., 1975. On the flow of water out of the Weddell Sea. DeepSea Research 22, 711-724.

Cohen, J.H., Forward, R.B., 2002. Spectral sensitivity of vertically migrating marine copepods. The Biological Bulletin 203, 307-314.

Connolley, W.M., 2005. Sea ice concentrations in the Weddell Sea: a comparison of SSM/I, ULS, and GCM data. Geophysical Research Letters 32, L07501, doi:10.1029/2004GL021898.

Cottier, F.R., Tarling, G.A., Wold, A., Falk-Petersen, S., 2006. Unsynchronized and synchronized vertical migration of zooplankton in a high Arctic fjord. Limnology and Oceanography 51, 2586-2599.

Deines, K.L., 1999. Backscatter estimation using broadband acoustic Doppler current profiles. IEEE, 249-253.

Everson, I., Ward, P., 1980. Aspects of Scotia Sea zooplankton. Biological Journal of the Linnean Society 14, 93-101.

Fach, B., Schmidt, G., Auerswald, L., Hayden, A., Herrmann, R., Hohn, S., Krägefsky, S., Meyer, B., 2007. Distribution of chlorophyll a in the Lazarev Sea. Reports on Polar and Marine Research 568, 56-57.

Fahrbach, E., Hoppema, M., Rohardt, G., Schröder, M., Wisotzki, A., 2004. Decadalscale variations of water mass properties in the deep Weddell Sea. Ocean Dynamics 54, 77-91.

Falk-Petersen, S., Leu, E., Berge, J., Kwasniewski, S., Nygård, H., Røstad, A., Keskinen, E., Thormar, J., v. Quillfeldt, C., Wold, A., Gulliksen, B., 2008. Vertical migration in high Arctic waters during autumn 2004. Deep-Sea Research II 55, 2275-2284.

Firing, E., 1991. Acoustic Doppler current profiling measurements and navigation. WOCE Hydrographic Program Office Report, WHPO 91-9, WOCE Report 68/91, 24pp.

Fischer, J., Visbeck, M., 1993. Seasonal variation of the daily zooplankton migration in the Greenland Sea. Deep-Sea Research I 40, 1547-1557.

Flagg, C.N., Smith, S.L., 1989. On the use of the acoustic Doppler Current profiler to measure zooplankton abundance. Deep-Sea Research 36, 465-474

Fofonoff, N.P., Millard, R.C., 1983. Algorithms for the computation of fundamental properties of seawater. UNESCO Technical Papers in Marine Science 44,1-53.

Fortier, M., Fortier, L., Hattori, H., Saito, H., Legendre, L., 2001. Visual predators and the diel vertical migration of copepods under Arctic sea ice during the midnight sun. Journal of Plankton Research 23, 1263-1278.

Forward, R.B., 1988. Diel vertical migration: zooplankton photobiology and behaviour. Oceanography and Marine Biology Annual Review 26, 361-393.

Francois, R.E., Garrison, G.R., 1982. Sound absorption based upon ocean measurements. Part II: boric acid contribution and equation for total absorption. Journal of the Acoustical Society of America 72, 1879-1890.

Frank, T.M., Widder, E.A., 1997. The correlation of downwelling irradiance and staggered vertical migration patterns of zooplankton in Wilkinson Basin, Gulf of Maine. Journal of Plankton Research 19, 1975-1991.

Gloersen, P., Campbell, W.J., 1991. Recent variations in Arctic and Antarctic sea-ice covers. Nature 352, 33-36.

Gordon, A.L., Huber, B.A., 1995. Warm Weddell Deep Water west of Maud Rise. Journal of Geophysical Research 100, 13747-13753.

Haney, J.F., 1988. Diel patterns of zooplankton behaviour. Bulletin of Marine Science 43, 583-603.

Hardy, A.C., Gunther, E.R., 1935. The plankton of South Georgia whaling grounds and adjacent waters 1926-1927. Discovery Report 11, 1-456.

Heywood, K.J., Scrope-Howe, S., Barton, E.D., 1991. Estimation of zooplankton abundance from shipborne ADCP backscatter. Deep-Sea Research 38, 677-691.

Heywood, K.J., 1996. Diel vertical migration of zooplankton in the northeast Atlantic. Journal of Plankton Research 18, 163-184.

Hunt, B.P.V., Pakhomov, E.A., Hosie, G.W., Siegel, V., Ward, P., Bernard, K., 2008 Pteropods in Southern Ocean ecosystems. Progress in Oceanography 78, 193-221.

Hutchinson, G.E., 1967. A Treatise on Limnology. Wiley, New York (p. 1115).

Jiang, S.N., Dickey, T.D., Steinberg, D.K., Madin, L.P., 2007. Temporal variability of zooplankton biomass from ADCP backscatter time series data at the Bermuda Testbed Mooring site. Deep-Sea Research I 54, 608-636.

Longhurst, A.R., Bedo, A.W., Harrison, W.G., Head, E.J.H., Sameoto, D.D., 1990. Vertical flux of respiratory carbon by oceanic diel migrant biota. Deep-Sea Research 37, 685-694.

Longhurst, A.R., Williams, R., 1992. Carbon flux by seasonal vertical migrant copepods is a small number. Journal of Plankton Research 14, 1495-1509.

Luo, J., Ortner, P.B., Forcucci, D., Cummings, S.R., 2000. Diel vertical migration of zooplankton and mesopelagic fish in the Arabian Sea. Deep-Sea Research II 47, 1451-1473.

Manuel, J.L., O’Dor, R.K., 1997. Vertical migration for horizontal transport while avoiding predators: I. A tidal/diel model. Journal of Plankton Research 19, 1929-1947.

Manuel, J.L., Pearce, C.M., O’Dor, R.K., 1997. Vertical migration for horizontal transport while avoiding predators: II. Evidence for the tidal/diel model from two populations of scallop (Placopecten magellanicus) veligers. Journal of Plankton Research 19, 1949-1973. 
McMinn, A., Ryan, K.G., Ralph, P.J., Pankowski, A., 2007. Spring sea ice photosynthesis, primary production and biomass distribution in eastern Antarctica, 2002-2004. Marine Biology 151, 985-995.

Nishikawa, J., Tsuda, A., 2001. Diel vertical migration of the tunicate Salpa thompsoni in the Southern Ocean during summer. Polar Biology 24, 299-302.

Nordhausen, W., 1994. Distribution and diel vertical migration of the euphausiid Thysanoessa macrura in Gerlache Strait, Antarctica. Polar Biology 14, 219-229.

Padman, L., Fricker, H.A., Coleman, R., Howard, S., Erofeeva, L., 2002. A new tide model for the Antarctic ice shelves and seas. Annals of Glaciological Society 34, 247-254.

Pagès, F., Schnack-Schiel, S.B., 1996. Distribution patterns of the mesozooplankton, principally siphonophores and medusae, in the vicinity of the Antarctic Slope Front (eastern Weddell Sea). Journal of Marine Systems 9, 231-248.

Pinot, J.M., Jansá, J., 2001. Time variability of acoustic backscatter from zooplankton in the Ibiza Channel (western Mediterranean). Deep-Sea Research I 48, 1651-1670.

Plueddemann, A.J., Pinkel, R., 1989. Characterization of the patterns of diel migration using a Doppler sonar. Deep-Sea Research 36, 509-530.

Record, N.R., de Young, B., 2006. Patterns of diel vertical migration of zooplankton in acoustic Doppler velocity and backscatter data on the Newfoundland Shelf Canadian Journal of Fisheries and Aquatic Sciences 63, 2708-2721.

Reda, I., Andreas, A., 2004. Solar position algorithm for solar radiation applications. Solar Energy 76, 577-589.

Ringelberg, J., 1995. Changes in light intensity and diel vertical migration: a comparison of marine and freshwater environments. Journal of the Marine Biology Association of the United Kingdom 75, 15-25.

Roe, H.S.J., 1974. Observations on the diurnal vertical migrations of an oceanic animal community. Marine Biology 28, 99-113.

Scharek, R., Smetacek, V., Fahrbach, E., Gordon, L.I., Rohardt, G., Moore, S., 1994. The transition from winter to early spring in the eastern Weddell Sea Antarctica: plankton biomass and composition in relation to hydrography and nutrients. Deep-Sea Research I 41, 1231-1250.
Schnack-Schiel, S.B., 2001. Aspects of the study of the life cycles of Antarctic copepods. Hydrobiologia 453-454, 9-24

Siegel, V., 2005. Distribution and population dynamics of Euphausia superba: summary of recent findings. Polar Biology 29, 1-22

Smith, W.O., Nelson, D.M., 1985. Phytoplankton bloom produced by a receding ice edge in the Ross Sea: spatial coherence with the density field. Science 227, 163-166.

Spiridonov, V.A., Nöthig, E.-M., Schröder, M., Wisotzki, A., 1996. The onset of biological winter in the eastern Weddell Gyre (Antarctica) planktonic community. Journal of Marine Systems 9, 211-230.

Stanton, T.K., Chu, D., 2000. Review and recommendations for the modelling of acoustic scattering by fluid-like elongated zooplankton: euphausiids and copepods. ICES Journal of Marine Science 57, 793-807.

Strass, V.H., 1998. Measuring sea ice draft and coverage with moored upward looking sonars. Deep-Sea Research I 45, 795-818.

Tanimura, A., Hattori, H., Miyamoto, Y., Hoshiai, T., Fukuchi, M., 2008. Diel changes in vertical distribution of Oithona similis (Cyclopoida) and Oncaea curvata (Poecilostomatoida) under sea ice in mid-summer near Syowa Station, Antarctica. Polar Biology 31, 561-567.

Tarling G.A. Matthews, J.B.L., David, P., Guerin, O., Buchholz, F, 2001. The swarm dynamics of northern krill (Meganyctiphanes norvegica) and pteropods (Cavolinia inflexa) during vertical migration in the Ligurian Sea observed by an acoustic Doppler current profiler. Deep-Sea Research I 48, 1671-1686.

Ward, P., Atkinson, A., Schnack-Schiel, S.B., Murray, A.W.A., 1997. Regional variation in the life cycle of Rhincalanus gigas (Copepoda: Calanoida) in the Atlantic sector of the Southern Ocean-re-examination of existing data (1928-1993) Marine Ecology Progress Series 157, 261-275.

Zaret, T.M., Suffern, J.S., 1976. Vertical migration in zooplankton as a predator avoidance mechanism. Limnology and Oceanography 21, 804-813.

Zwally, H.J., Comiso, J.C., Parkinson, C.L., Cavalieri, D.J., Gloersen, P., 2002 Variability of Antarctic sea ice 1979-1998. Journal of Geophysical Research 107, 3041, doi:10.1029/2000JC000733. 